\title{
Structural classification and biological activities of Stemona alkaloids
}

\author{
Harald Greger 1
}
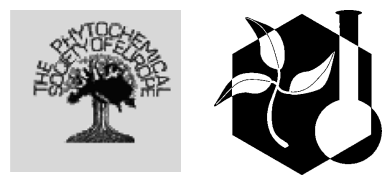

Received: 11 February 2019/Accepted: 27 February 2019/Published online: 19 March 2019

(C) The Author(s) 2019

\begin{abstract}
Stemona alkaloids represent a unique class of natural products exclusively known from the three genera Stemona, Stichoneuron, and Croomia of the monocotyledonous family Stemonaceae. Structurally they are characterized by a central pyrroloazepine core usually linked with two butyrolactone rings. The great diversity, comprising 215 derivatives, is created by the formation of additional $C-C$ linkages and oxygen bridges together with ring cleavages and eliminations of the lactone rings. Based on biosynthetic considerations they can be grouped into three structural types represented by the croomine, stichoneurine, and protostemonine skeleton. Due to the formation of characteristic terminal lactone rings and the central pyrrolidine ring pandanamine and pandamarilactonine, isolated from Stichoneuron calcicola, were suggested to represent biogenetic precursors. The taxonomically complex $S$. tuberosa group can be clearly segregated by the formation of stichoneurines, while the other Stemona species are characterized by protostemonine derivatives. Croomine derivatives are more widespread found in both groups and in the genus Croomia. Of chemotaxonomic significance are the different transformations of protostemonine into stemofolines with a cage-type structure or into
\end{abstract}

H. Greger $(\bowtie)$

Chemodiversity Research Group, Faculty of Life

Sciences, University of Vienna, Rennweg 14,

1030 Vienna, Austria

e-mail: harald.greger@univie.ac.at pyridoazepines characterized by a six-membered piperidine ring. Stimulated by the great interest in the antitussive activity of Stemona alkaloids, differences in transport mechanisms and potencies via different administrative routes were investigated. Follow-up studies on the significant insecticidal activities focused on the mode of action by using biochemical and electrophysiological approaches. Screening for acetylcholinesterase inhibitory properties revealed a much higher potency for stemofoline derivatives compared to pyridoazepines, but showed also significant activity for isomers of stenine with a stichoneurine skeleton. Evaluating synergistic growth inhibitory effects with cancer chemotherapeutic agents stemofoline exhibited the most potent effect in the reversal of permeability glycoprotein-mediated multidrug resistance. The anti-inflammatory activity of some derivatives was identified as an inhibition of the expression of inflammatory mediators. Comparing the diverse bioactivities of Stemona alkaloids stemofoline-type derivatives are the most versatile compounds representing promising lead structures for further development as commercial agents in agriculture and medicine.

Keywords Stemona alkaloids $\cdot$ Structural classification - Biogenetic trends - Antitussive activity - Insecticidal and nematicidal activity . Acetylcholinesterase inhibition · Multidrug resistance 
reversing properties - Anti-inflammatory activities . Chemotaxonomy

\section{Introduction}

In the framework of UNESCO's program "Man and the Biosphere" (MAB) broad-based phytochemical investigations within tropical plant families were carried out in our laboratory to find a replenishing source of naturally occurring insecticides or fungicides. Besides highly active sulfur-containing amides from the genus Glycosmis of the Rutaceae (Greger et al. 1996; Hofer and Greger 2000) and flavaglines from Aglaia of the Meliaceae (Brader et al. 1998; Bacher et al. 1999) we found very promising biological activities in the genus Stemona of the small monocotyledonous family Stemonaceae (Brem et al. 2002; Pacher et al. 2002). As reviewed previously the high insecticidal activity could be attributed to family-specific Stemona alkaloids (Greger 2006), whereas the antifungal property was caused by different groups of stilbenoids (Greger 2012). In addition, the accumulation of tocopherols with antioxidant activity was shown to represent another chemical character of that family (Brem et al. 2004). Apart from sporadic reports on iminosugars (Asano et al. 2005) and chlorogenic acid derivatives (Ge et al. 2007) continuative investigations mainly focused on Stemona alkaloids due to their unique molecular structures and wide range of bioactivities. Synthetic approaches to their intricate structures were summarized in a microreview by Alibés and Figueredo (2009) and more recent advances were reviewed by Liu and Wang (2015). A number of innovative strategies have been developed recently for the construction of the structurally simplest stemoamide (214) (Brito and Pirovani 2018). Moreover, extensive chromatographic comparisons of extracts from wild and cultivated Stemona species provided the basis for chemotaxonomic conclusions as well as for hypotheses regarding biosynthetic connections within this class of alkaloids (Schinnerl et al. 2007; Kongkiatpaiboon et al. 2011).

Although the basic biosynthetic steps in the formation of Stemona alkaloids are still unknown different suggestions regarding the origin of the central building blocks have been published (Seger et al. 2004; Greger et al. 2009; Wang and Chen 2014). Structural classifications were based either on pure chemical perspectives (Pilli et al. 2010) or on biosynthetic considerations (Greger 2006; Wang and Chen 2014). As a result, Stemona alkaloids were classified either into eight groups by Pilli et al. (2010), or into two classes with fourteen types by Wang and Chen (2014). By contrast, only three basic skeletons were discriminated by Greger (2006). The present review provides an updated classification of 215 Stemona alkaloids including all newly described derivatives. In spite of the many new structures the overview supports the previous classification into three basic skeletons (Tables 1, 2, 3) based on presumed biosynthetic connections and on the distribution of specific structures in related species (Fig. 1).

In continuation of the previous review (Greger 2006) reports on bioactivties were summarized indicating remarkable progress in deciphering the mode of action. Stimulated by the great interest in the antitussive activity of Stemona alkaloids, investigations on differences in transport mechanisms and potencies via different administrative routes were carried out (Lin et al. 2008a, b; Leung et al. 2006; Zhou et al. 2009). Moreover, different ways to prepare structurally diverse analogues of active compounds were elaborated to find an efficient synthetic route (Frankowski et al. 2008, 2011). In continuation of previous investigations on insecticidal activities (Sakata et al. 1978; Jiwajinda et al. 2001; Brem et al. 2002; Kaltenegger et al. 2003) follow-up studies focused on the mode of action by using biochemical and electrophysiological approaches (Tang et al. 2008). With regard to the acetylcholinesterase inhibiting properties of Stemona alkaloids, bioassays with naturally-occurring as well as synthetically prepared derivatives informed about structure-activity relationships (Wang et al. 2007a; Baird et al. 2009; Chaiyong et al. 2010; Sastraruji et al. 2010, 2012; Ramli et al. 2013, 2014; Lai et al. 2013). Following the first report on multidrug resistance properties of an ethanolic extract of Stemona aphylla (Limtrakul et al. 2007), a series of studies evaluated the synergistic growth inhibitory effect of Stemona alkaloids with cancer chemotherapeutic agents (Chanmahasathien et al. 2011a, b; Umsumarng et al. 2013, 2015, 2017, 2018). Furthermore, their anti- 
Table 1 Structures derived from croomine skeleton<smiles>CC(C)C(=O)O[C@@H]1CCCCN2[C@@H]([C@H]3C[C@H](C)C(=O)O3)CC[C@]12C</smiles>

1 croomine Noro et al. 1979<smiles>CO[C@H]1CCCN2[C@H]([C@H]3C[C@H](C)C(=O)O3)CC[C@H]2[C@]12C[C@@H](C)C(=O)O2</smiles>

4 stemospironine Sakata et al. 1978<smiles></smiles>

9 dehydrocroomine Lin et al.2008b

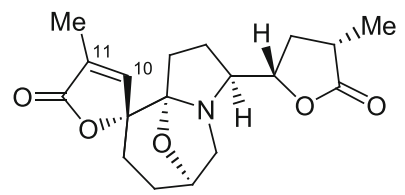

12 dehydroisostemotinine Guo et al. 2010

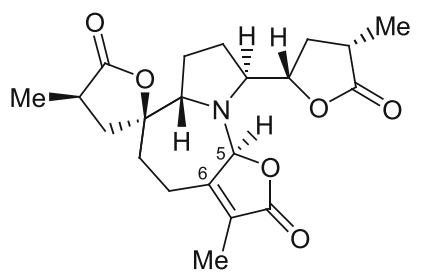

15 stemona-amine A Hitotsuyanagi et al. 2013a (= sessilifoliamine $\mathrm{A}$ Hitotsuyanagi et al. 2008)<smiles>C[C@H]1C[C@H]([C@@H](O)CC[C@H]2NCCCC[C@]23C[C@H](C)C(=O)O3)OC1=O</smiles>

2 tuberocrooline Lin et al. $2008 b$<smiles>C[C@@H]1C[C@H](C2CC[C@@]34CCCCN3[C@H]2OC(=O)[C@@H]4O)OC1=O</smiles>

5 10-hydroxycroomine Lin et al. $2008 b$<smiles></smiles>

10 stemotinine

Xu et al. 1982<smiles>C[C@H]1C[C@H]([C@H]2CC[C@@]3(CCC(=O)N4O[C@@]5(CC43)C[C@H](C)C(=O)O5)OC2=O)OC1=O</smiles>

13 stemona-lactam J Hitotsuyanagi et al. 2013a (= sessilifoliamide $\mathrm{J}$ Hitotsuyanagi et al. 2008)<smiles>C[C@H]1C[C@H]([C@H]2CC[C@@H]3N2C[C@H](O)CC[C@@]32C[C@H](C)C(=O)O2)OC1=O</smiles>

3 6-hydroxycroomine Jiang et al. 2006a

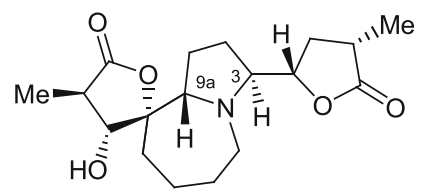

6 tuberospironine Jiang et al. 2006b

7 tuberospironine $\mathrm{A}[\mathrm{H}-3 \beta]$ Pudjiastuti et al. 2012

8 9a-epi-tuberospironine $(\mathrm{H}-9 \mathrm{a} \alpha)$ Yue et al. 2013<smiles></smiles>

11 isostemotinine Xu et al. 1982<smiles>C[C@H]1C[C@H](c2ccc3n2CCCC[C@]32C[C@H](C)C(=O)O2)OC1=O</smiles>

14 didehydrocroomine Lin et al. 1993a<smiles>C[C@@H]1C[C@]2(CCCCN3C(=O)CC[C@H]32)OC1=O</smiles>

16 tuberostemospiroline Hu et al. 2009<smiles>C[C@H]1C[C@@]2(CCCCN3C(=O)CC[C@H]32)OC1=O</smiles>

17 tuberostemospironine Lin et al. 1992<smiles>C[C@@H]1C(=O)O[C@H]2CCCCN3C(=O)CC[C@H]2[C@H]13</smiles>

18 stemo-lactam R Hitotsuyanagi et al. 2013a 
Table 2 Structures derived from stichoneurine skeleton

(I) stemoninine-type derivatives

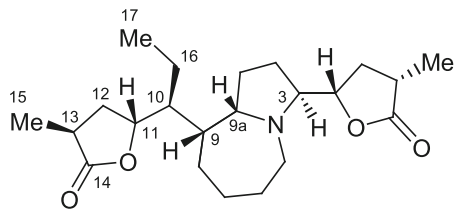

19 stichoneurine $A$

20 stichoneurine B [Et-10 $\alpha]$

Schinnerl et al. 2005

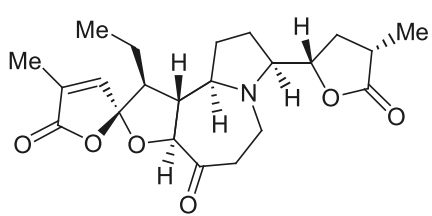

25 stemoninone Hu et al. 2009

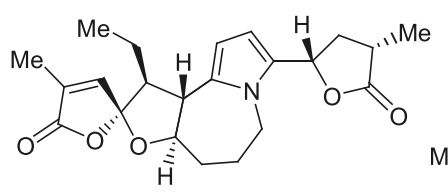

29 isobisdehydrostemoninine Lin et al. 2006

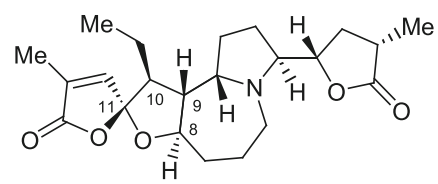

21 stemoninine

Cheng et al. 1988

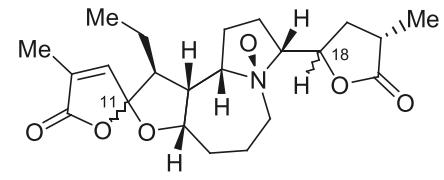

22 stichoneurine C [11R, 18S]

23 stichoneurine $D$ [11S, 18S]

24 stichoneurine $E$ [11R, 18R]

Ramli et al. 2013<smiles>CC1=C[C@]2(OC1=O)O[C@H]1CCCn3c([C@H]4C[C@H](C)C(=O)O4)ccc3[C@]12CO</smiles>

28 bisdehydrostemoninine Lin et al. 2006
26 stemoenonine $[\mathrm{R}=\mathrm{OH}]$ 27 9a-O-methylstemoenonine $[\mathrm{R}=\mathrm{OMe}] \quad$ Lin et al. 2008a

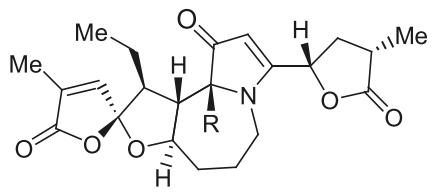

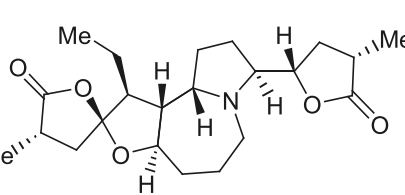

30 dihydrostemoninine Wang et al. 2007a

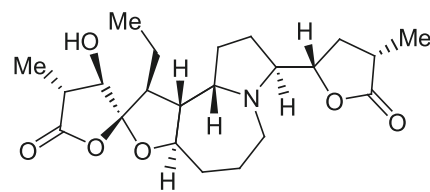

31 oxystemoninine Lin et al. 2008a

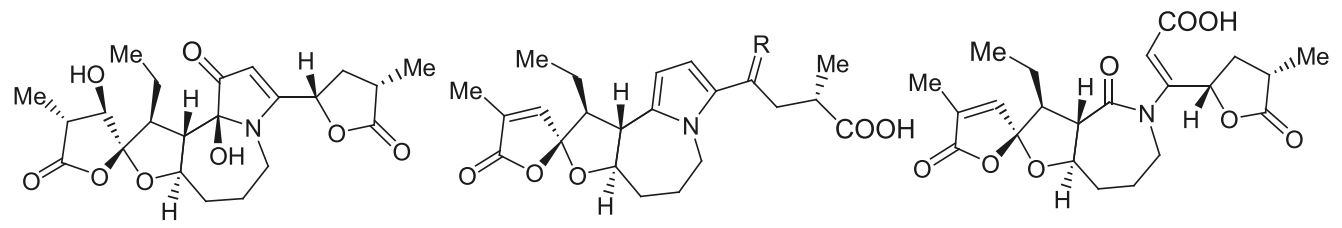

32 oxystemoenonine Lin et al. 2008a
33 bisdehydrostemoninine $B[R=H, H]$ 34 bisdehydrostemoninine $A[R=O]$ Lin et al. 2006

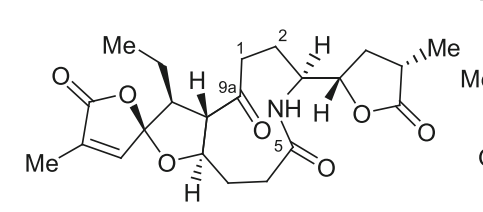

36 stemona-lactam $\mathrm{N}$ Hitotsuyanagi et al. 2013a

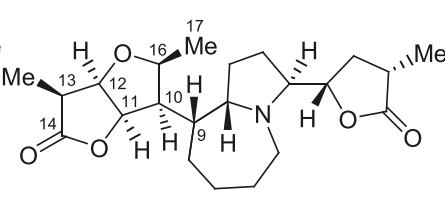

37 parvistemonine Lin et al. 1990

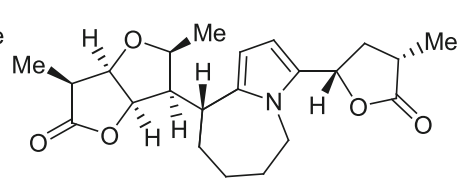

38 didehydroparvistemonine Lin et al. 1991a

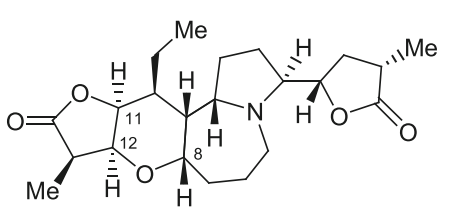

39 stemona-amine $\mathrm{F}$ Hitotsuyanagi et al. 2016

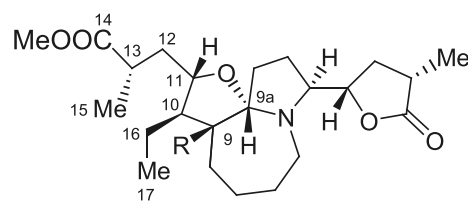

40 stichoneurine $\mathrm{F} \mathrm{R}=\mathrm{H}$ 41 stichoneurine $\mathrm{G} \mathrm{R}=\mathrm{OH}$ Ramli et al. 2014<smiles>C[C@H]1O[C@H]2[C@@H](OC1=O)[C@@H]2[C@H]1CCCCN2C(=O)CC[C@@H]12</smiles>

42 parvistemoline Lin et al. 1991a 
Table 2 continued<smiles>CC[C@H]1[C@@H]2[C@@H]3CCC(=O)N3CCC[C@H]2O[C@@]12C[C@@H](C)C(=O)O2</smiles>

43 stemona-lactam A Hitotsuyanagi et al. 2013a (= sessilifoliamide A Kakuta et al. 2003)<smiles>CC[C@H]1C2c3cccn3CCC[C@H]2O[C@@]12C=C(C)C(=O)O2</smiles>

46 bisdehydroneostemoninine Lin et al. 2006<smiles>CC[C@H](C1CCCCN2C(=O)CC[C@@H]12)[C@H]1C=C(C)C(=O)O1</smiles>

49 stemona-lactam C Hitotsuyanagi et al. 2013a (= sessilifoliamide C Kakuta et al. 2003)<smiles>CC[C@H]1[C@H]2CCCCN3C(=O)CC[C@@H]2O[C@H]13</smiles>

44 stemoninoamide Lin et al. 1994<smiles>CCC1[C@H]2C(=O)NCCC[C@H]2O[C@]12C=C(C)C(=O)O2</smiles>

47 stemona-lactam S Fukaya et al. 2013<smiles>CCC(C(=O)C[C@@H](C)C(C)=O)[C@H]1CCCCN2C(=O)CC[C@H]12</smiles>

50 stemona-lactam D Hitotsuyanagi et al. 2013a (= sessilifoliamide D Kakuta et al. 2003)<smiles>CC[C@@H]1[C@@H]2[C@H](CCCN3C(=O)C=C[C@]23O)O[C@@]12C=C(C)C(=O)O2</smiles>

45 stemona-lactam $\mathrm{O}$ Hitotsuyanagi et al. 2013a<smiles>CC[C@@H]([C@H]1C[C@@H](C)C(=O)O1)[C@H]1CCCCN2C(=O)CC[C@H]12</smiles>

48 stemona-lactam B Hitotsuyanagi et al. 2013a (= sessilifoliamide $\mathrm{B}$ Kakuta et al. 2003)

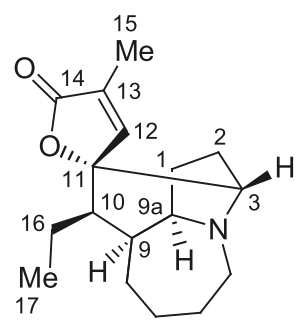

51 parvineostemonine Ke et al. 2003

II tuberostemonine-type derivatives

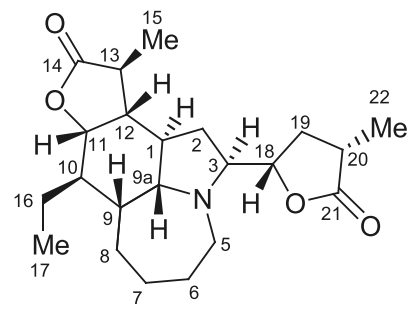

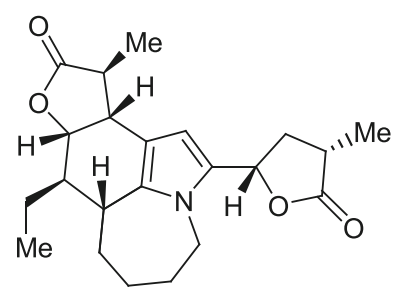


Table 2 continued

52 tuberostemonine Harada et al. 1967

53 tuberostemonine $A$ $[\mathrm{H}-3 \beta]$

Edwards et al. 1962

54 tuberostemonine B $[\mathrm{H}-10 \beta]$

55 tuberostemonine $\mathrm{C}$ $[\mathrm{H}-9 \alpha, \mathrm{H}-10 \beta]$

Zou et al. 1999

56 tuberostemonine $\mathrm{N}$ $[\mathrm{H}-13 \beta]$

Schinnerl et al. 2007

57 tuberostemonine $D$ [H-3 $\beta, \mathrm{H}-18 \alpha]$

Zhang et al. 2014

58 tuberostemonine $O$ $[\mathrm{H}-9 \mathrm{a} \alpha]$

Kil et al. 2014
59 neotuberostemonine $[\mathrm{H}-1 \beta, \mathrm{H}-11 \alpha, \mathrm{H}-12 \alpha]$

Ye et al. 1994a

60 tuberostemonine $\mathrm{H}$

$[\mathrm{H}-1 \beta, \mathrm{H}-9 \mathrm{a} \alpha, \mathrm{H}-11 \alpha, \mathrm{H}-12 \alpha]$

61 tuberostemonine $\mathrm{J}$

$[\mathrm{H}-1 \beta, \mathrm{H}-9 \alpha, \mathrm{H}-9 \mathrm{a} \alpha, \mathrm{H}-11 \alpha$,

$\mathrm{H}-12 \alpha$ ] Chung et al. 2003

62 tuberostemonine $\mathrm{K}$

$[\mathrm{H}-11 \alpha, \mathrm{H}-12 \alpha]$

Jiang et al. 2006b

63 tuberostemonine $\mathrm{L}$

$[\mathrm{H}-1 \beta, \mathrm{H}-18 \alpha, \mathrm{H}-20 \alpha, \mathrm{H}-11 \alpha, 12 \alpha]$

64 tuberostemonine $\mathrm{M}$

$[\mathrm{H}-1 \beta, \mathrm{H}-3 \beta, \mathrm{H}-9 \mathrm{a} \alpha, \mathrm{H}-18 \alpha$, $\mathrm{H}-11 \alpha, \mathrm{H}-12 \alpha]$

Sastraruji et al. 2006

65 tuberostemonine "L"

$[\mathrm{H}-1 \beta, \mathrm{H}-9 \mathrm{a} \alpha, \mathrm{H}-11 \alpha, \mathrm{H}-12 \alpha, 13 \beta]$

Hu et al. 2009
66 bisdehydrotuberostemonine

Edwards et al. 1962

67 bisdehydroneotuberostemonine

$[\mathrm{H}-11 \alpha, \mathrm{H}-12 \alpha]$

Ye et al. 1994a

$689 \alpha$-bisdehydrotuberostemonine [H-9 $\alpha$ ]

Lin et al. $2008 \mathrm{~b}$

69 bisdehydrotuberostemonine $B$ [H-10 $\beta$ ]

70 bisdehydrotuberostemonine $C$ $[\mathrm{H}-9 \alpha, \mathrm{H}-10 \beta]$

Zou et al. 1999

71 isodidehydrotuberostemonine $[\mathrm{H}-9 \alpha, \mathrm{H}-13 \beta, \mathrm{H}-18 \alpha]$

Lin and $\mathrm{Fu} 1999$

72 epi-bisdehydroneotuberostemonine $\mathrm{J}$ $[\mathrm{H}-9 \alpha, \mathrm{H}-13 \alpha, \mathrm{H}-18 \alpha]$

Chung et al. 2003

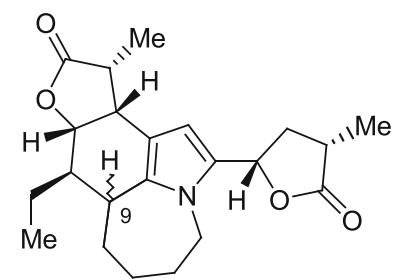

73 bisdehydrotuberostemonine $D[\mathrm{H}-9 \beta]$ 74 bisdehydrotuberostemonine $E[\mathrm{H}-9 \alpha]$

Gao et al. 2014

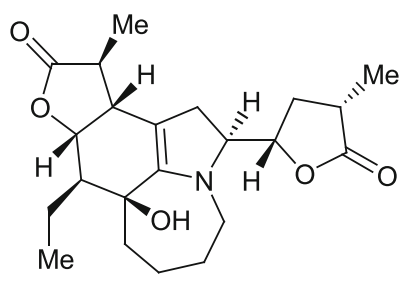

77 tuberostemonol Lin et al. 1992<smiles>CC[C@@H]1[C@H](C)c2cc(CC[C@H](O)C(=O)O)n3c2[C@@H]1CCCC3</smiles>

$759 \alpha$-bisdehydrotuberostemonine $A$ Lin et al. 2008b<smiles>CC[C@@H]1CCCCN2C3=C1[C@H]1OC(=O)[C@H](C)[C@@H]1[C@@]3(O)C[C@H]2[C@H]1C[C@H](C)C(=O)O1</smiles>

78 neotuberostemonol Jiang et al. 2002

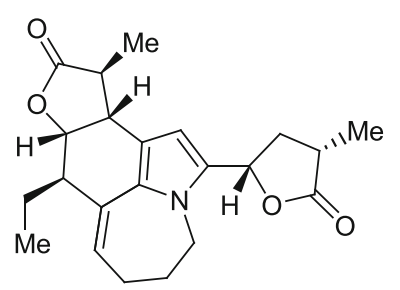

76 tridehydrotuberostemonine Lin et al. $2008 b$

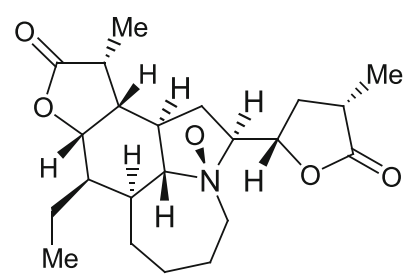

$79 \mathrm{~N}$-oxytuberostemonine Lin and Fu 1999 
Table 2 continued

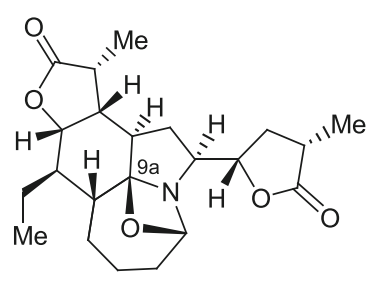

80 sessilifoline $A$

Qian and Zhan 2007

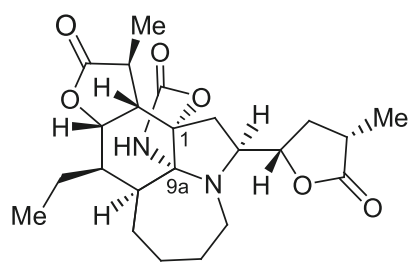

83 stemoxazolidinone $\mathrm{E}$ Hitotsuyanagi et al. 2011

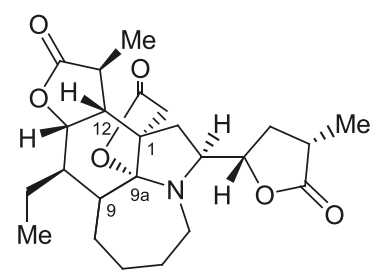

86 stemona-amine $\mathrm{E}$ Hitotsuyanagi et al. 2013b

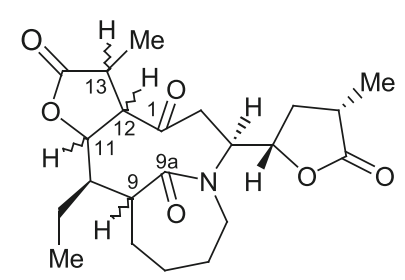

89 tuberostemonone $[\mathrm{H}-9 \alpha, \mathrm{H}-11 \beta, \mathrm{H}-12 \beta, \mathrm{H}-13 \alpha]$ Hitotsuyanagi et al. 2007a 90 neotuberostemonone $[\mathrm{H}-9 \beta, \mathrm{H}-11 \beta, \mathrm{H}-12 \beta, \mathrm{H}-13 \beta]$ Cai and Luo 2007

91 stemonatuberone $\mathrm{A}$ $[\mathrm{H}-9 \beta, \mathrm{H}-11 \beta, \mathrm{H}-12 \beta, \mathrm{H}-13 \alpha]$ 92 stemonatuberone $\mathrm{B}$ $[\mathrm{H}-9 \beta, \mathrm{H}-11 \alpha, \mathrm{H}-12 \alpha, \mathrm{H}-13 \beta]$ 93 stemonatuberone $\mathrm{C}$ $[\mathrm{H}-9 \beta, \mathrm{H}-11 \beta, \mathrm{H}-12 \alpha, \mathrm{H}-13 \alpha]$ Yue et al. 2014

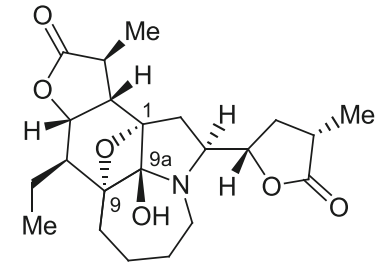

81 stemona-amine B Hitotsuyanagi et al. 2013a

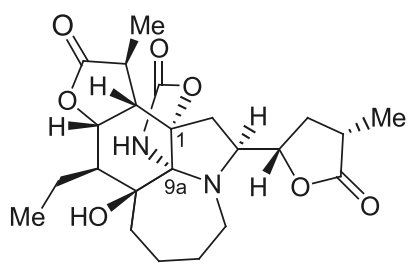

84 stemoxazolidinone D Hitotsuyanagi et al. 2011

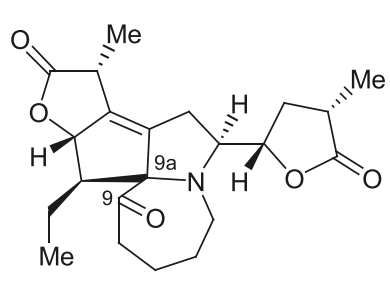

87 tuberostemoenone Cui and Lin 1998

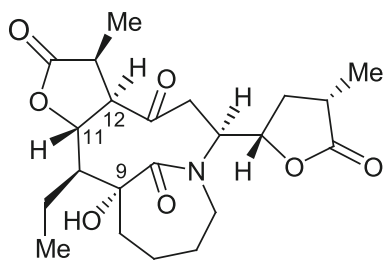

94 stemona-lactam H Hitotsuyanagi et al. 2013a (= sessilifoliamide $\mathrm{H}$ Hitotsuyanagi et al. 2007a)

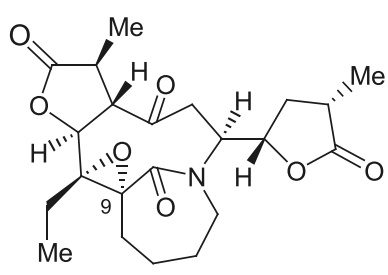

96 epoxytuberostemonone Cai and Luo 2007<smiles>CC[C@H]1[C@H]2OC(=O)[C@@H](C)[C@H]2[C@@]2(O)C[C@@H]([C@H]3C[C@@H](C)C(=O)O3)N3CCCC[C@@]12O3</smiles>

82 tuberostemonoxirine Yue et al. 2013

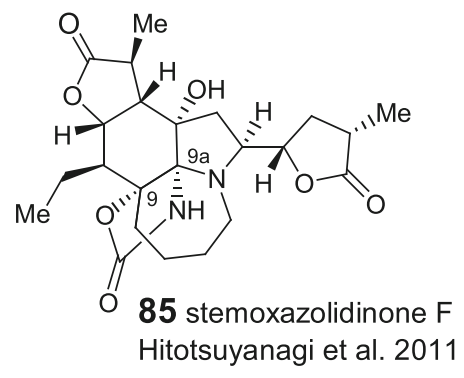<smiles>CCC1CCCCN2C3=C1[C@H]1[C@H](C)C(=O)O[C@]3(C[C@H]2[C@H]2C[C@H](C)C(=O)O2)[C@@H]1O</smiles>

88 oxotuberostemonine Kondo et al. 1954; Huber et al. 1968

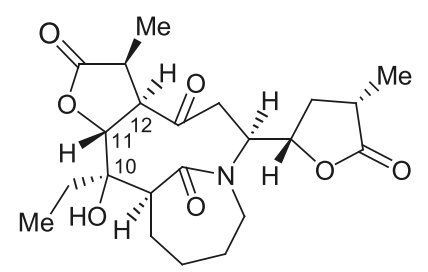

95 stemonatuberonol A Yue et al. 2014

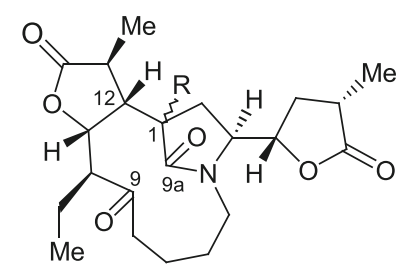

97 stemona-lactam $\mathrm{E}[\mathrm{R}=\mathrm{H}-1 \beta]$ 98 stemona-lactam $\mathrm{F}[\mathrm{R}=\mathrm{OH}-1 \beta]$ Hitotsuyanagi et al. 2007a, 2013a 99 tuberostemoline $[\mathrm{R}=\mathrm{OH}-1 \alpha]$ Lin et al. $2008 b$ 
Table 2 continued

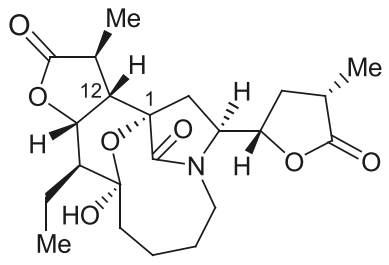

100 stemona-lactam G Hitotsuyanagi et al. 2013a (= sessilifoliamide $\mathrm{G}$ Hitotsuyanagi et al. 2007a)

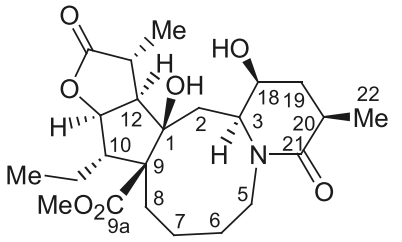

103 stemona-lactam $\mathrm{K}$ Hitotsuyanagi et al. 2013a (= sessilifoliamide $\mathrm{K}$ Hitotsuyanagi et al. 2010)

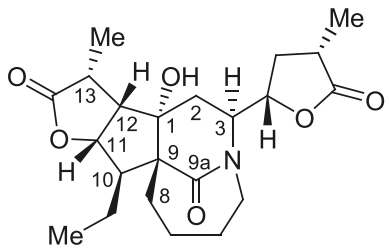

106 tuberostemoninol Lin et al. 1994

107 neotuberostemoninol $[\mathrm{H}-11 \alpha, \mathrm{H}-12 \alpha]$ Jiang et al. 2002 108 stemona-lactam $Q$ $\left[\mathrm{OH}-1 \beta, \mathrm{C}_{8}-9 \alpha, \mathrm{C}_{13}-\mathrm{Me} \beta\right]$ Hitotsuyanagi et al. 2013a 109 stemona-lactam I $\left[\mathrm{OH}-1 \beta, \mathrm{C}_{8}-9 \alpha, \mathrm{C}_{10}-\mathrm{Et} \alpha, \mathrm{C}_{13}-\mathrm{Me} \beta\right]$ Hitotsuyanagi et al. 2007b, 2013a 110 tuberostemoninol $\mathrm{A}$ $\left[\mathrm{H}-11 \alpha, \mathrm{H}-12 \alpha, \mathrm{C}_{13}-\mathrm{Me} \beta\right]$ Zhong et al. 2010

111 tuberostemoninol B $[\mathrm{H}-3 \beta, \mathrm{OH}-1 \beta$ ]

Zhong et al. 2010

112 tuberostemoninol C $\left[\mathrm{C}_{13}-\mathrm{Me} \beta\right]$

Gao et al. 2014

113 stemonatuberosine $A$ $\left[\mathrm{C}_{13}-\mathrm{Me} \beta\right]$

Yue et al. 2014

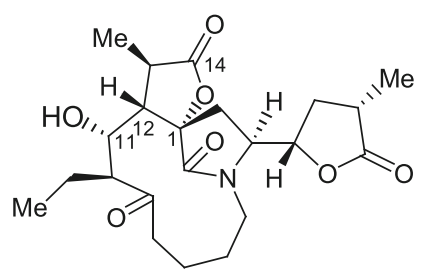

101 tuberostemoline A Gao et al. 2014<smiles>CC[C@H]1C2=C(C[C@H]3[C@@H](O)C[C@@H](C)C(=O)N3CCCCC2)[C@H]2[C@@H](C)C(=O)O[C@H]12</smiles>

104 stemona-lactam L Hitotsuyanagi et al. 2013a (= sessilifoliamide L

Hitotsuyanagi et al. 2010)

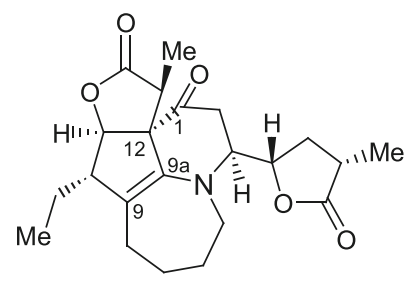

114 stemosessifoine Guo et al. 2008

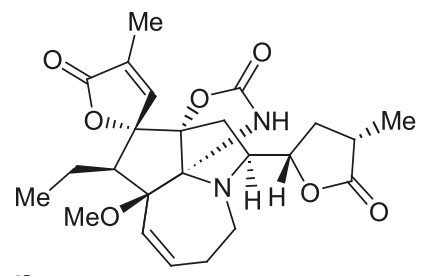

117 stemoxazolidinone C Hitotsuyanagi et al. 2011

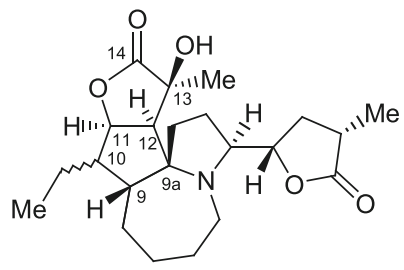

119 sessilistemonamine $\mathrm{A}\left[\mathrm{C}_{10}-\mathrm{Et} \alpha\right]$ 120 sessilistemonamine $C\left[C_{10}-E t \beta\right]$ Wang et al. 2007a

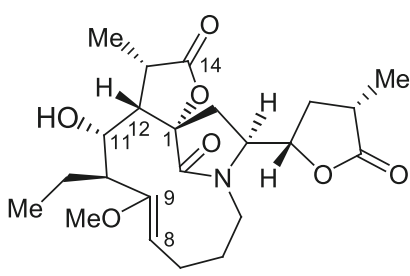

102 stemona-lactam M Hitotsuyanagi et al. 2013a

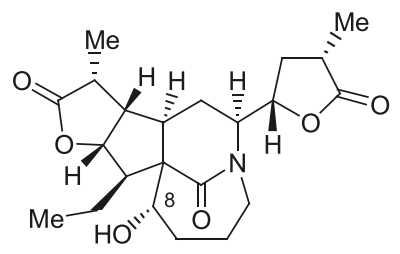

105 maireistemoninol

Cai and Luo 2007

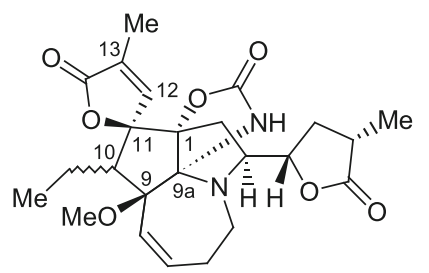

115 stemoxazolidinone $\mathrm{A}\left[\mathrm{C}_{10}-\mathrm{Et} \beta\right]$ 116 stemoxazolidinone $\mathrm{B}\left[\mathrm{C}_{10}-\mathrm{Et} \alpha\right.$ ] Hitotsuyanagi et al. 2011

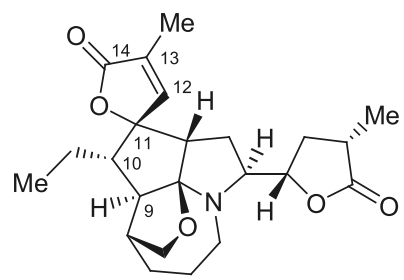

118 stemona-amine G Hitotsuyanagi et al. 2016

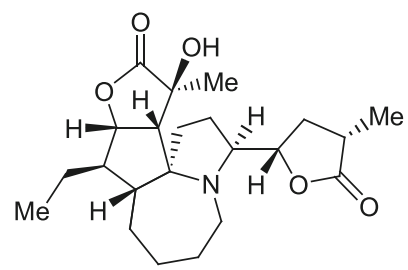

121 sessilistemonamine $B$ Wang et al. 2007a 
Table 2 continued

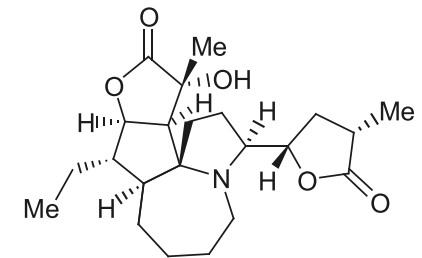

122 sessilistemonamine $\mathrm{F}$ 123 sessilistemonamine $\mathrm{E}$ [C $10-\mathrm{Et} \beta$ ] Ramli et al. 2014

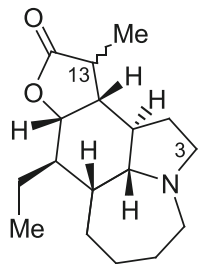

127 stenine $\left[\mathrm{C}_{13}-\mathrm{Me} \beta\right.$ ] Harada et al. 1967 128 stenine $\mathrm{B}\left[\mathrm{C}_{13}-\mathrm{Me} \alpha\right]$ Lai et al.2013

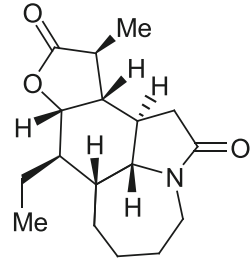

132 2-oxostenine Götz et al.1968 Kakuta et al. 2003 124sessilistemonamine D Wang et al. $2007 \mathrm{~b}$

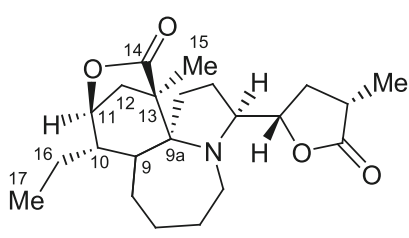

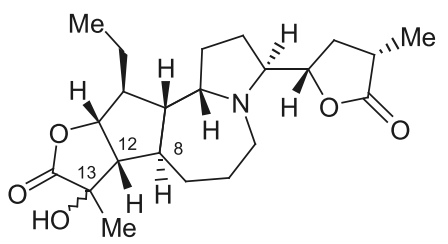

125 stemona-amine $\mathrm{C}[\mathrm{OH}-13 \beta]$ 126 stemona-amine $\mathrm{D}[\mathrm{OH}-13 \alpha]$ Hitotsuyanagi et al. 2013b

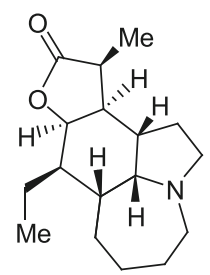

129 neostenine Chung et al. 2003

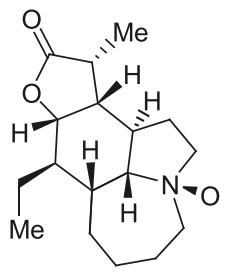

130 stenine $A$ Lai et al. 2013

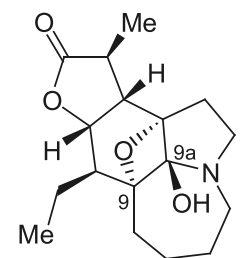

131 1,9-epoxy-9ahydroxystenine Gao et al. 2014

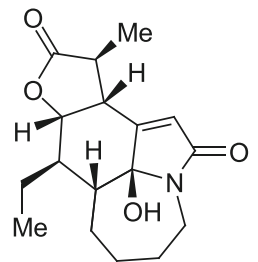

133 stemona-lactam $P$ Hitotsuyanagi et al. 2013a
134 dehydrostenine $A$ 135 dehydrostenine $B$ $\left[\mathrm{C}_{10}-\mathrm{Et} \alpha, \mathrm{C}_{13}-\mathrm{Me} \alpha\right]$ Dong et al. 2017
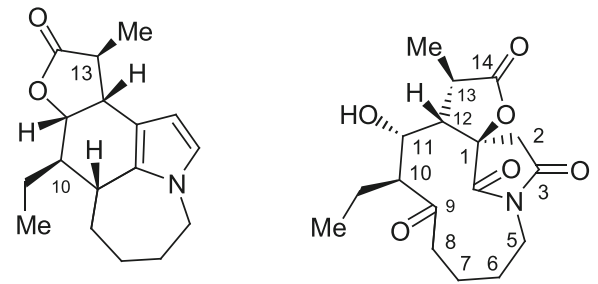

136 tuberostemoline B Gao et al. 2014 inflammatory activity was investigated and regarded as an inhibition of the expression of diverse inflammatory mediators (Hosoya et al. 2011; Lim et al. 2015; Jung et al. 2016; Lee et al. 2016; Wu et al. 2018). The present review also reports on the nematicidal activity (Huang et al. 2016; Chen et al. 2018) and other miscellaneous properties as well as on the pharmacokinetics of that class of alkaloids (Dong et al. 2012; Sun et al. 2012; Han et al. 2016). Formula depictions facilitate an overview of 215 derivatives demonstrating structural relationships and biogenetic trends also serving as a guide for exploiting these compounds for further development as useful agents in agriculture and medicine.

\section{Structural classification}

Stemona alkaloids are characterized by a pyrrolo[1,2a] azepine core (rings A, B) usually linked with two $\alpha$ methyl- $\gamma$-butyrolactone rings $(C, D)$. As shown in the structural overview (Tables 1, 2, 3) they can be derived from three basic skeletons differing in the substitution at $C-9$ (Fig. 1). This classification was also supported by broad-based chemotaxonomic studies within the genus Stemona indicating two clear-cut trends either towards derivatives with a stichoneurine or protostemonine skeleton (Jiang et al. 2006b; Schinnerl et al. 2007; Li et al. 2007a; Kongkiatpaiboon et al. 2011). In contrast, derivatives with a croomine 
Table 3 Structures derived from protostemonine skeleton

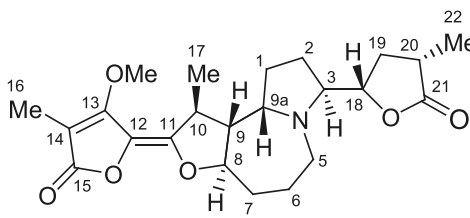

137 protostemonine Irie et al. 1970a

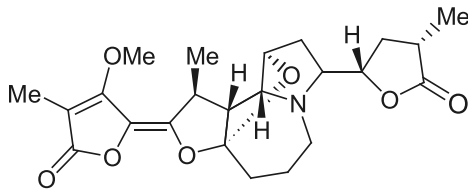

141 oxyprotostemonine Kaltenegger et al. 2003<smiles>COC1=C(C)C(=O)O/C1=C1\O[C@@H]2CCCn3c([C@H]4C[C@H](C)C(=O)O4)ccc3[C@H]2[C@H]1C</smiles>

144 bisdehydroprotostemonine Ye et al. 1994b

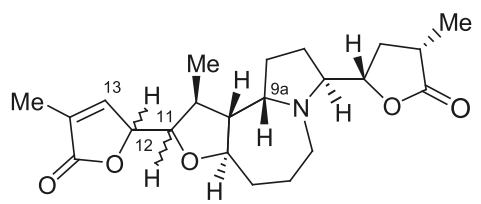

148 stemocochinine [11S, 12S] 14913-demethoxy-[11S,12R]dihydroprotostemonine

Tang et al. 2008

150 javastemonine $\mathrm{A}[\mathrm{H}-9 \mathrm{a} \alpha, \mathrm{H}-11 \beta$, $\mathrm{H}-12 \alpha$ ] Ramli et al. 2015

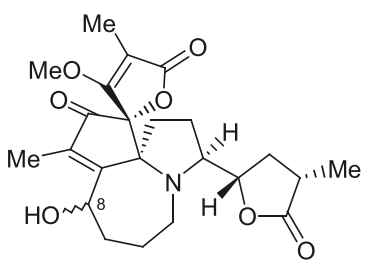

155 oxymaistemonine $\left[\mathrm{C}_{8}-\mathrm{OH} \beta\right]$ Lin et al. 1991c,d

156 isooxymaistemonine $\left[\mathrm{C}_{8}-\mathrm{OH} \alpha\right]$ Guo et al. 2008

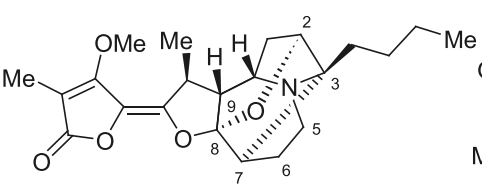

160 stemofoline Irie et al. 1970b

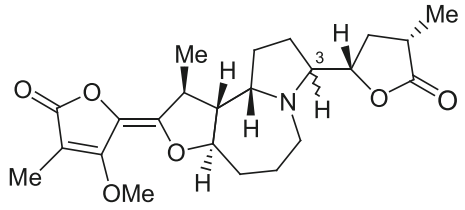

138 isoprotostemonine $[\mathrm{H}-3 \alpha]$ Ye et al. 1994b

139 javastemonine $\mathrm{B}[\mathrm{H}-3 \beta]$

Ramli et al. 2015

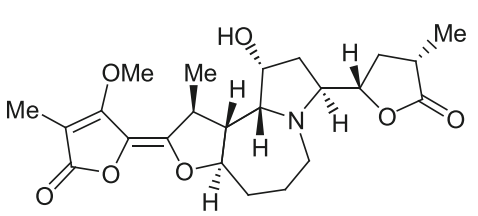

142 1-hydroxyprotostemonine Chaiyong et al. 2010<smiles>COC1=C(C)C(=O)O/C1=C1\OC2=CCCN3[C@H]([C@H]4C[C@H](C)C(=O)O4)CC[C@]3(C)[C@H]2[C@H]1C</smiles>

140 dehydroprotostemonine Kaltenegger et al. 2003<smiles>COC1=C(C)C(=O)O/C1=C1\OC2CCCN(O)[C@]3(C[C@H]4C[C@H](C)C(=O)O4)CC[C@H]2[C@H]1[C@@H]3C</smiles>

143 protostemonine- $N$-oxide Huang et al. 2016

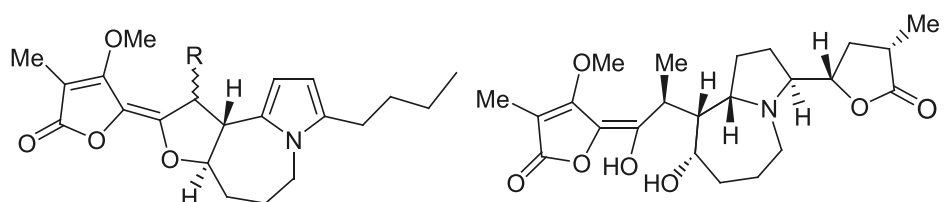

1453 - $n$-butylneostemonine $[\mathrm{R}=\beta \mathrm{Me}]$ 146 10-epi-3-n-butylneostemonine $[\mathrm{R}=\alpha \mathrm{Me}]$ Huang et al. 2016<smiles>CC1=C[C@H]([C@H]2O[C@H]3CCCn4c([C@H]5C[C@H](C)C(=O)O5)ccc4[C@@]3(C)[C@H]2C)OC1=O</smiles>

151 bisdehydrostemocochinine [12R] 152 isobisdehydrostemocochinine [12S] Lin et al. 2007b<smiles>CCCC[C@H]1CC[C@]23C(=C(C)C(=O)[C@]24OC(=O)C(OC)=C4OC)CCCN13</smiles>

$1573 \beta$-n-butylstemonamine $[\mathrm{R}=\mathrm{H}, \mathrm{H}]$ 158 8-oxo-3 $\beta$ - $n$-butylstemonamine $[R=$ O] Huang et al. 2016
147 protostemodiol Tang et al. 2008

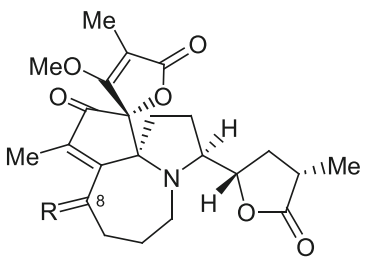

153 maistemonine $[\mathrm{R}=\mathrm{H}, \mathrm{H}]$ Lin et al. 1991c,d

154 8-oxo-oxymaistemonine $[R=0]$ Huang et al. 2016

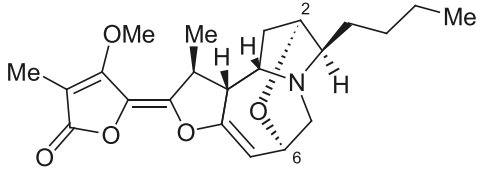

159 neostemofoline Tang et al. 2008

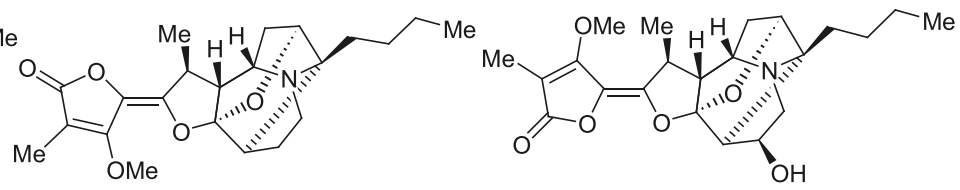

161 isostemofoline Ye and Velten 2003
$1626 \beta$-hydroxystemofoline Tang et al. 2008 
Table 3 continued

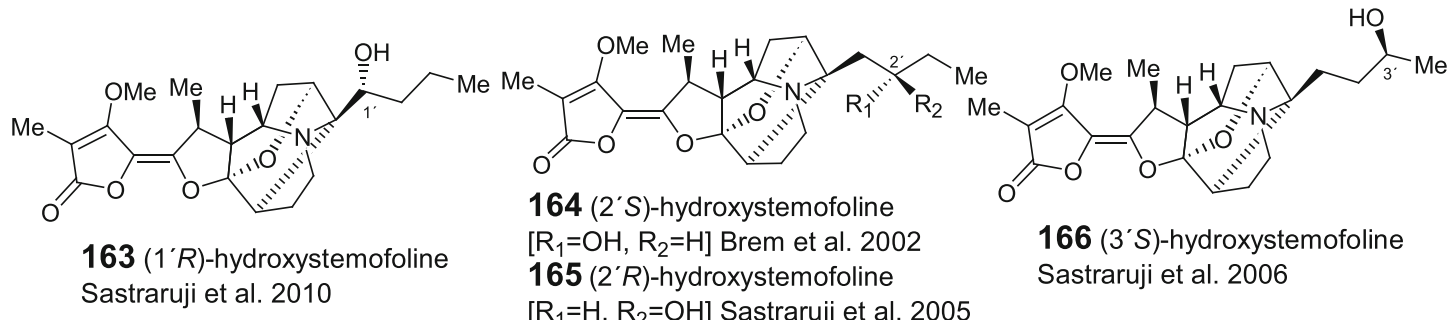

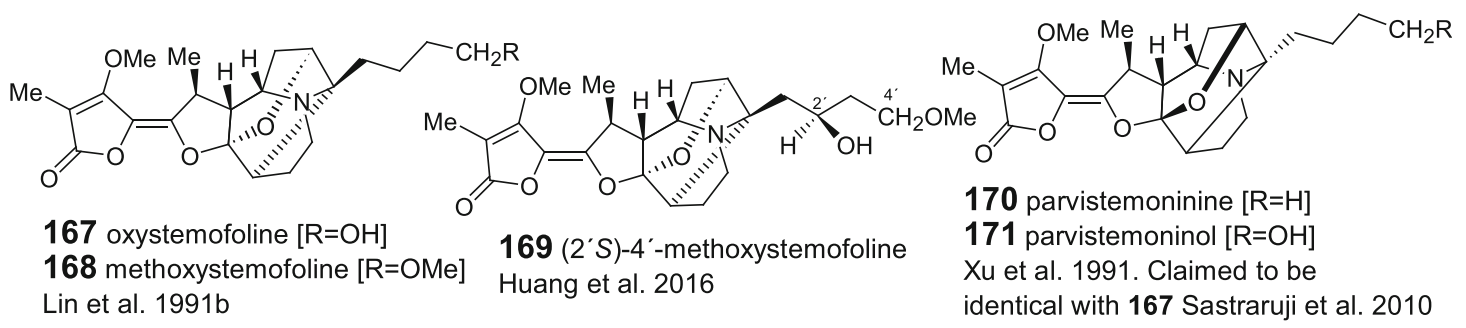

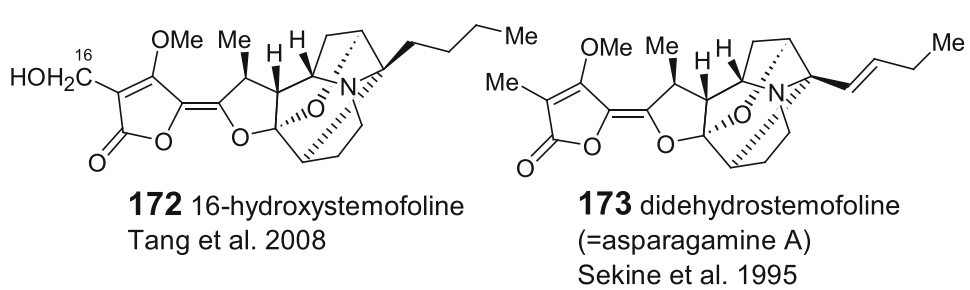

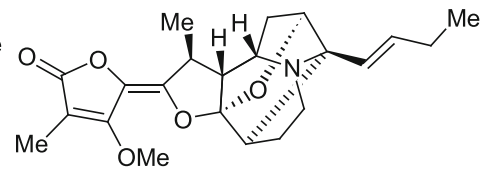

174 isodidehydrostemofoline Jiwajinda et al. 2001

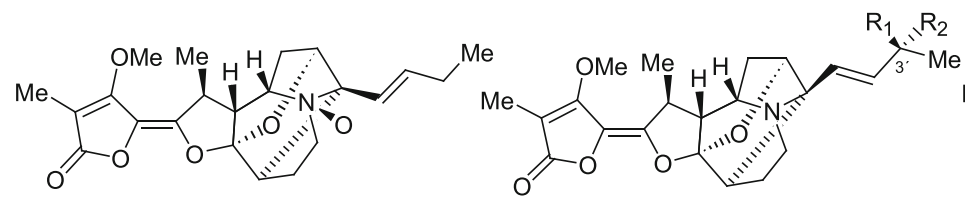

175 didehydrostemofoline$\mathrm{N}$-oxide Sastraruji et al. 2005 $176\left(3^{\prime} R\right)$-stemofolenol $\left[\mathrm{R}_{1}=\mathrm{OH}, \mathrm{R}_{2}=\mathrm{H}\right]$ 177 (3'S)-stemofolenol $\left[\mathrm{R}_{1}=\mathrm{H}, \mathrm{R}_{2}=\mathrm{OH}\right]$ Sastraruji et al. 2005

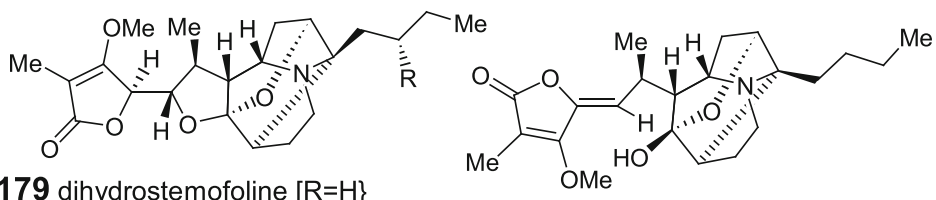

179 dihydrostemofoline $[\mathrm{R}=\mathrm{H}\}$ Mungkornasawakul et al. 2004b 180 2' -hydroxydihydrostemofoline $[\mathrm{R}=\mathrm{OH}]$ Sastraruji et al. 2011
181 stemoburkilline Sastraruji et al. 2009

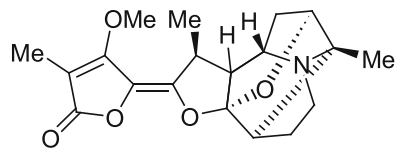

182 methylstemofoline Sastraruji et al. 2005 
Table 3 continued

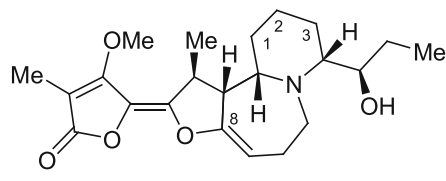

183 stemokerrine Kaltenegger et al. 2003

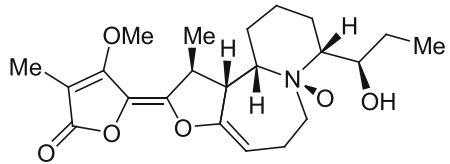

184 stemokerrine$\mathrm{N}$-oxide Wang et al. 2007b

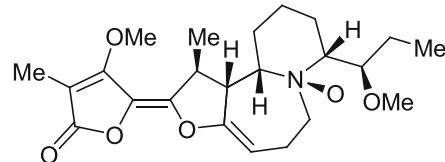

185 methoxystemokerrine$\mathrm{N}$-oxide

Kaltenegger et al. 2003

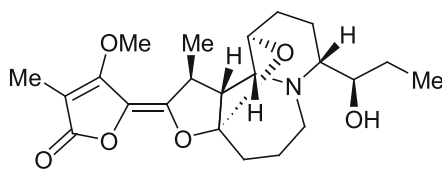

186 oxystemokerrine Kaltenegger et al. 2003

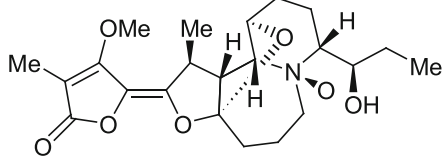

187 oxystemokerrine$\mathrm{N}$-oxide Kaltenegger et al. 2003

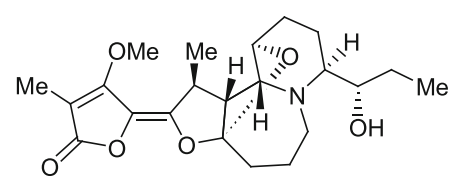

188 stemocurtisinol Mungkornasawakul et al. $2004 a$

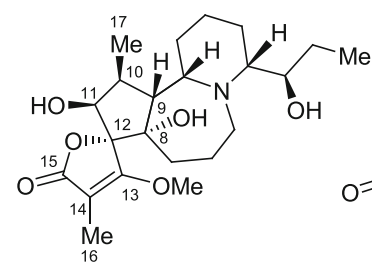

189 cochinchistemonine Lin et al. 2007a

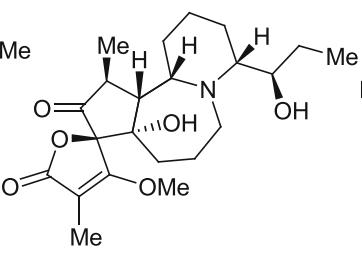

190 cochinchistemoninone Wang et al. 2007b

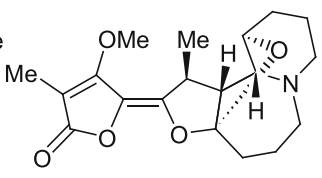

191 stemocurtisine Mungkornasawakul et al. 2003

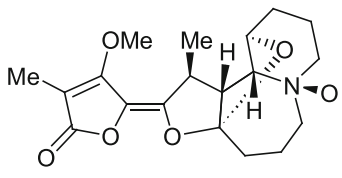

192 stemocurtisine- $\mathrm{N}$-oxide Chaiyong et al. 2010

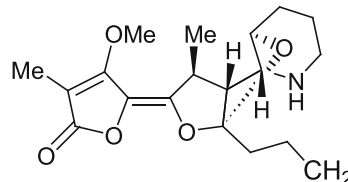

193 6-hydroxy-5,6-secostemocurtisine Mungkornasawakul et al. 2013<smiles>COC1=C(C)C(=O)OC1=C(O)C(O)C1CCCN2CCCCC12</smiles>

197 neostemodiol Ye and Xu 1992

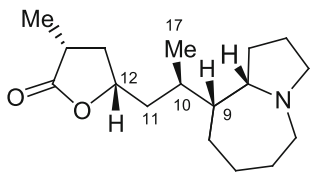

204 stemaphylline Mungkornasawakul et al. 2009

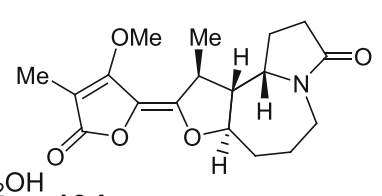

194 protostemonamide Yang et al. 2009

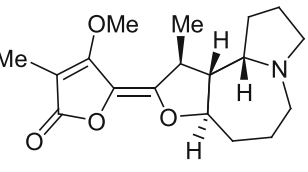

195neostemonine Ye et al. 1994b<smiles>COC1=C(C)C(=O)O/C1=C1\O[C@@H]2CCCn3cccc3[C@]2(C)C1(C)C</smiles>

196 bisdehydroneostemonine Ye et al. 1994b
200 neostemocochinine [12R] Lin et al. 2007b 201 isoneostemocochinine [12S] Lin et al. 2014

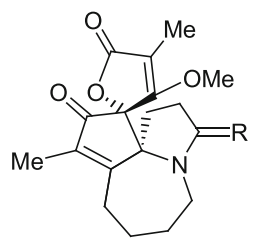

205 stemaphylline- $\mathrm{N}$-oxide 206 stemonamine $[\mathrm{R}=\mathrm{H}, \mathrm{H}]$ lizuka et al. 1973

207 stemonamide $[R=0$ ] Ye et al. 1994c

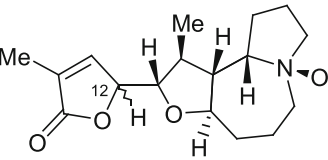

202 neostemocochinine- $N$ oxide [12R]

203 isoneostemocochinine$\mathrm{N}$-oxide [12S] Lin et al. 2014

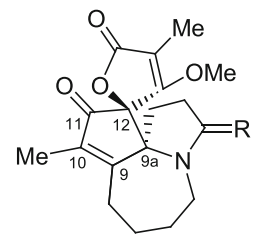

208 isostemonamine $[\mathrm{R}=\mathrm{H}, \mathrm{H}]$ lizuka et al. 1973 209isostemonamide $[R=0]$ Ye et al. 1994c 
Table 3 continued

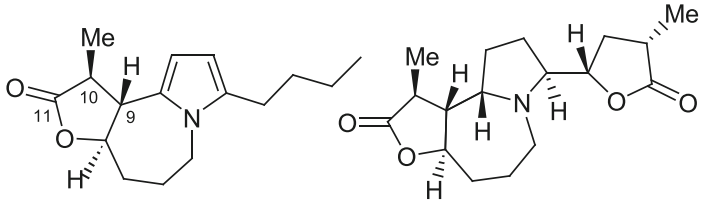

210 parvistemonine $A$ Huang et al. 2016
211 stemonine Koyama \& Oda 1970

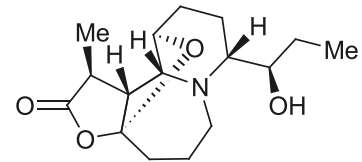

212 oxystemokerrilactone Wang et al. 2007b

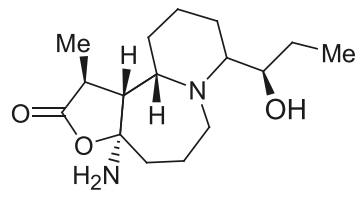

213 stemocochinamine Lin et al. 2007b

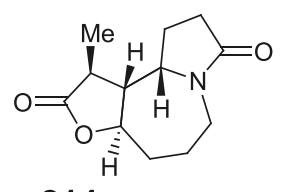

214 stemoamide Lin et al. 1992<smiles>CC1(C)O[C@@H]2CCC(=O)NCCC[C@@H]2OC1=O</smiles>

215 parvistemoamide Lin et al. 1991a
Fig. 1 Three basic structures of Stemona alkaloids (Greger 2006)

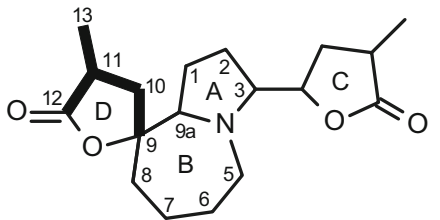

croomine skeleton

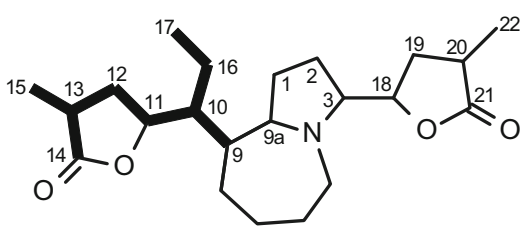

stichoneurine skeleton

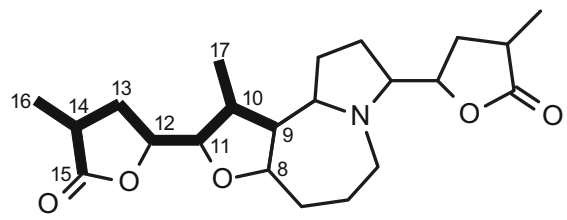

protostemonine skeleton skeleton were shown to be more widespread cooccurring with the other two skeletal types, and were also isolated from the genus Croomia (Noro et al. 1979; Jiang et al. 2006a; But et al. 2012).

Concerning the biosynthetic pathway the two $C_{5^{-}}$ units, forming the lactone rings $\mathrm{C}$ and $\mathrm{D}$, were previously proposed to be of terpenoid origin, and the pyrroloazepine nucleus derived from an iminiumion-based reaction of a spermidine unit $\left(C_{3} N C_{4}\right)$ (Seger et al. 2004). This hypothetical route was recently also considered by Wang and Chen (2014). However, the unexpected discovery of the secondary amine pandanamine as major constituent in the genus Stichoneuron, a sister genus of Croomia (Inthachub et al. 2009), let expect an alternative formation of
Stemona alkaloids (Greger et al. 2009). As shown in Fig. 2 the formation of the two lactone rings and the cyclization to a pyrrolidine ring in the co-occurring pandamarilactonine strongly suggests close structural relations to croomine (1). In this case the two characteristic terminal lactone rings were supposed to be derived from leucine via 4-hydroxy-4-methylglutamic acid, and the symmetrical central building block from a $\mathrm{C}_{4} N C_{4}$ dicarboxylic acid, probably derived from two glutamic acid units (Takayama et al. 2000). Pandanamine was originally isolated from the leaves of Pandanus amaryllifolius Roxb. (Pandanaceae) (Takayama et al. 2001) and was shown to be accompanied by a series of closely related derivatives 


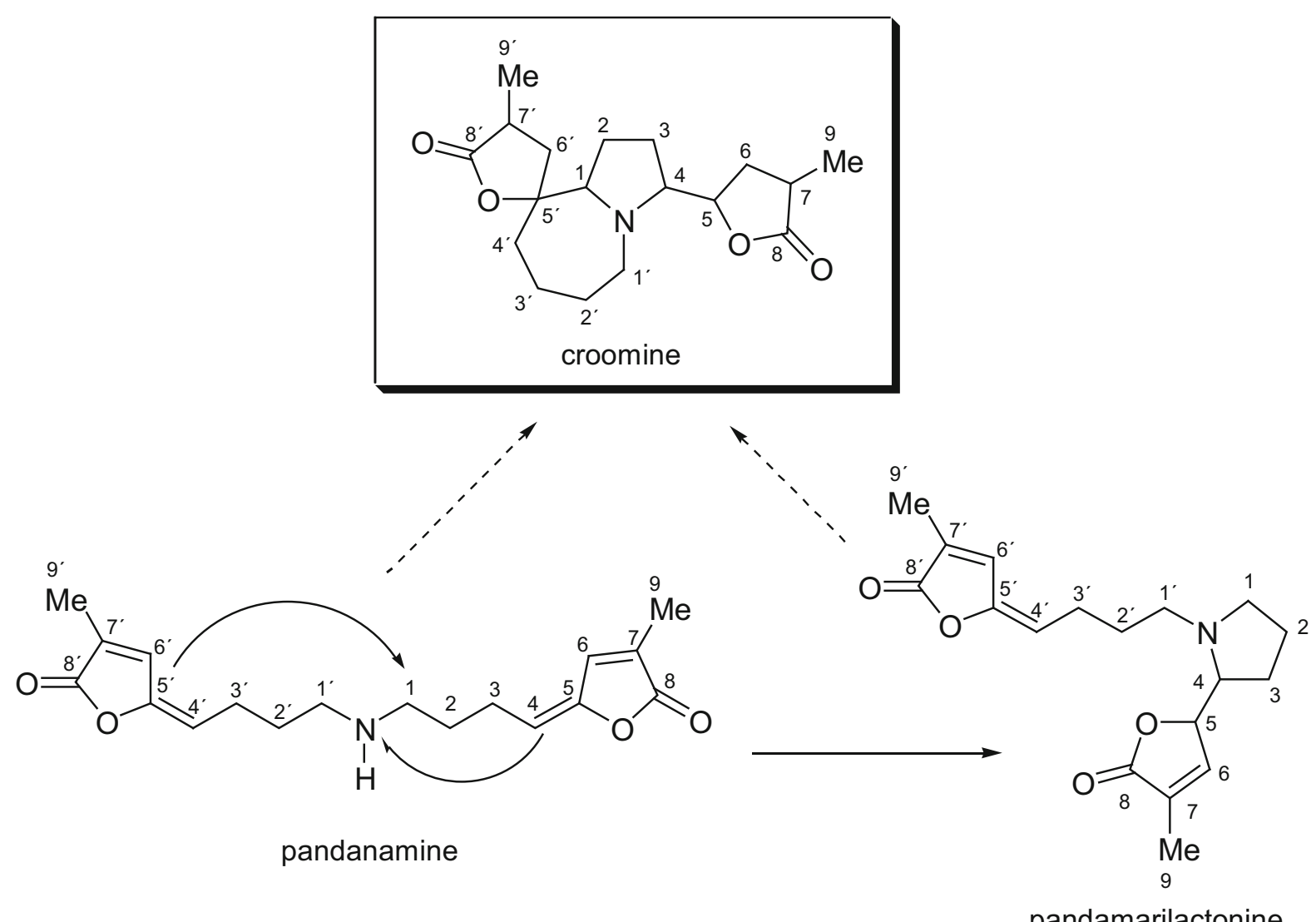

Fig. 2 Pandanamine and pandamarilactonine isolated from Stichoneuron calcicola as possible precursors of the croomine skeleton (Greger et al. 2009)

collectively called Pandanus alkaloids (Tsai et al. 2015).

\section{Croomines}

Compounds with a croomine skeleton represent the smallest group of Stemona alkaloids comprising so far only 18 derivatives. A typical structural feature is the position of lactone ring $\mathrm{D}$, which is directly attached to the azepane ring $\mathrm{B}$ at $C-9$, forming a spiro system (Table 1). Modifications are created by different oxygenations at rings $\mathrm{B}(\mathbf{3}, \mathbf{4}, \mathbf{1 3})$ and $\mathrm{D}(\mathbf{5}-\mathbf{8}, \mathbf{1 7}$, 18), and the formation of an oxygen-bridge between $C$-6 and $C-9 \mathrm{a}$ in the stemotinines (10-12). Tuberostemospiroline (16), tuberostemospironine (17), and stemo-lactam R (18) deviate by the loss of lactone ring $\mathrm{C}$, and stemona-amine $\mathrm{A}(\mathbf{1 5})$ by an additional butyrolactone ring fused with the azepane ring at $C-5-$ $C$-6. In the case of stemona-lactam $\mathrm{J}(\mathbf{1 3})$ the seven- membered azepane ring B is contracted to a sixmembered piperidine-2-one ring (Hitotsuyanagi et al. 2008).

The great structural diversity of Stemona alkaloids is build up mainly by stichoneurine and protostemonine derivatives (Tables 2, 3). Important transformation steps are additional $C-C$ linkages and oxygenbridges either between lactone ring $\mathrm{D}$ and the pyrroloazepine core (Fig. 3) or within the central nucleus (Fig. 5). Further frequent modifications are created by elimination of the lactone rings, which was suggested to be the result of hydrolysis and oxidative cleavage (Fig. 4) (Lai et al. 2013), and the transformation of pyrrolidine ring $\mathrm{A}$ of the protostemonines into a piperidine ring (Kaltenegger et al. 2003). The latter step is accompanied by opening lactone ring $\mathrm{C}$ linked with chain-shortening by decarboxylation (Fig. 5). 


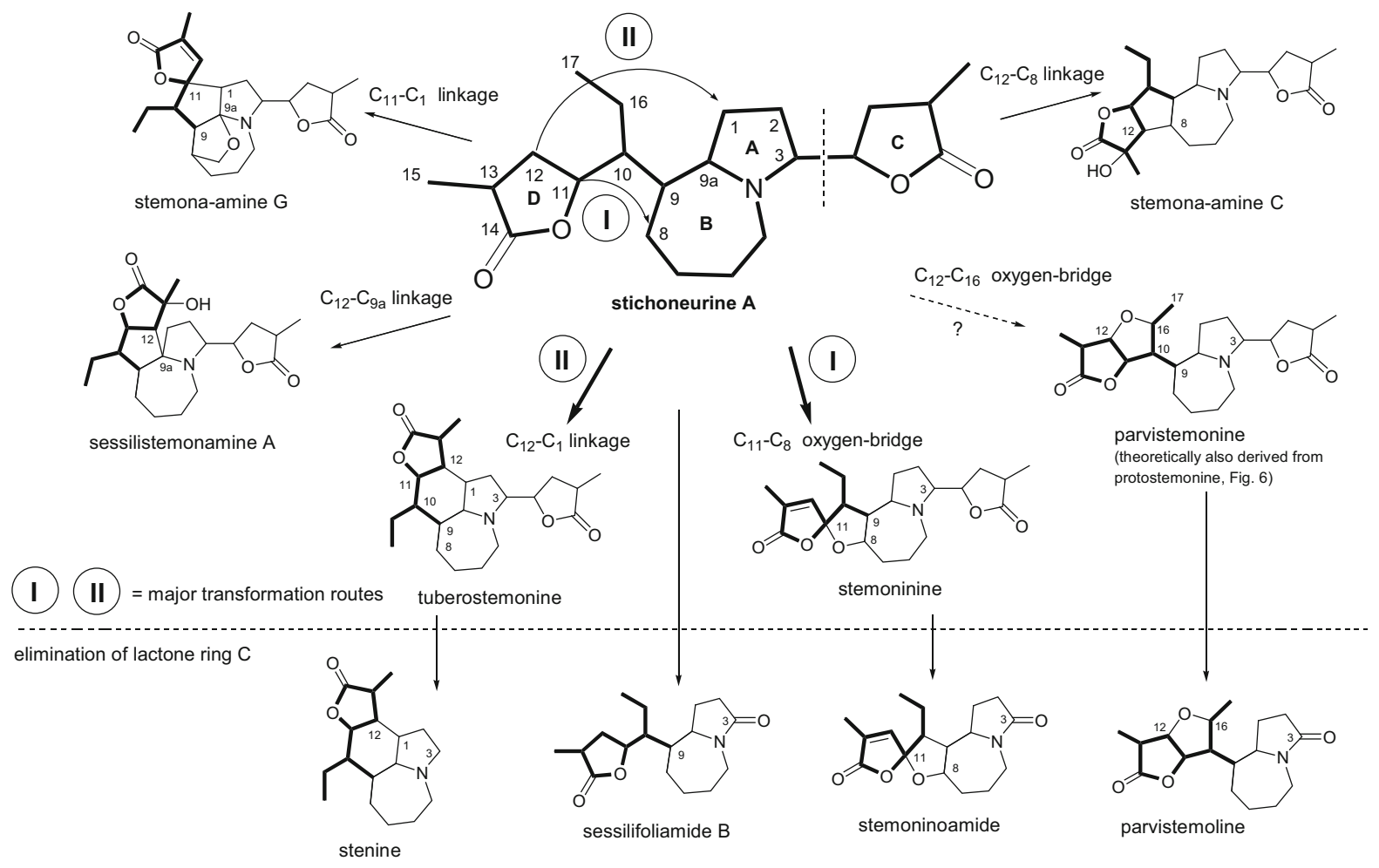

Fig. 3 Proposed transformations of stichoneurine derived structures

Stichoneurines

Common to all stichoneurine derivatives is the ethyl group $(C-16-C-17)$ attached at $C-10$. Another common trend is the frequent elimination of lactone ring $\mathrm{C}$. As shown in Fig. 3 two major transformation steps (I, II) lead either to stemoninine- or to tuberostemoninetype derivatives created by an $C-11-C-8$ oxygenbridge or by a $C-C$ linkage between $C-12$ and $C-1$, respectively. In some compounds $C-12$ was also shown to be linked with $C$-9a (sessilistemonamines 119-123) or with $C-8$ (stemona-amines C, D (125, 126)), and $C$-11 linked with $C$-1, forming a spiro system [stemona-amine $G(\mathbf{1 1 8})$, stemoxazolidinones A-C (115-117)]. A unique linkage between $C-13$ and $C-9$ a was reported for sessilistemonamine D (124) (Wang et al. 2007b). Parvistemonine (37) and the related didehydroparvistemonine (38) and parvistemoline (42) deviate by an unusual oxygen-bridge between $C-12$ and $C$-16 (Lin et al. 1990, 1991a). Since these compounds are known so far only from Stemona species which are otherwise characterized by protostemonine derivatives, they were only tentatively listed in the stemoninine group (Table 2). A possible alternative formation is shown in Fig. 6.

\section{Stemoninine-type derivatives (I)}

Apart from the formation of isomers (20, 22-24, 29) structural variation of the stemoninine-type derivatives is mainly based on different oxygenations (2224, 26, 27, 32) and dehydrogenations (26-29, 32-34, 38, 46) of the pyrrolidine ring A together with ring cleavages in 1,9a-seco-stemoenonine (35), stemonalactam N (36), and stemona-lactam S (47). Additional modification is created by the elimination of lactone ring $\mathrm{C}$ (42-51) frequently leading to a 3-oxo group. An unusual linkage between $C-11$ and $C-3$ was reported for parvineostemonine (51) isolated from the stem and leaves of S. parviflora (Ke et al. 2003).

\section{Tuberostemonine-type derivatives (II)}

A higher degree of diversification is generated in derivatives of the tuberostemonine-type. Tuberostemonine (52) itself was shown to occur with many 

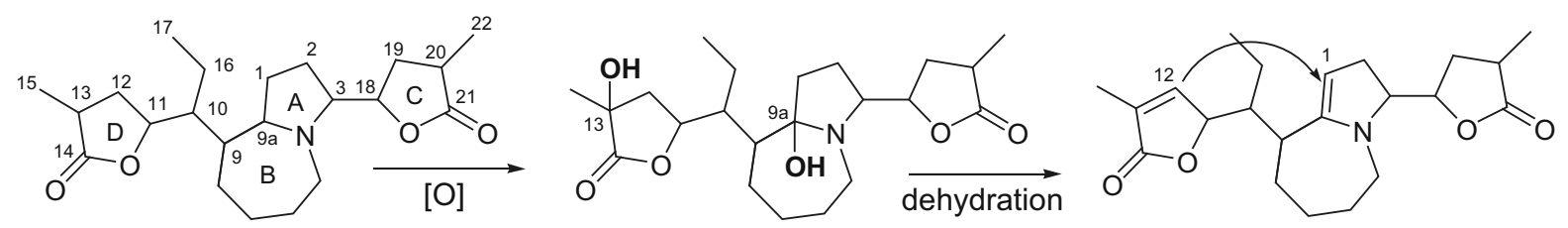

stichoneurine
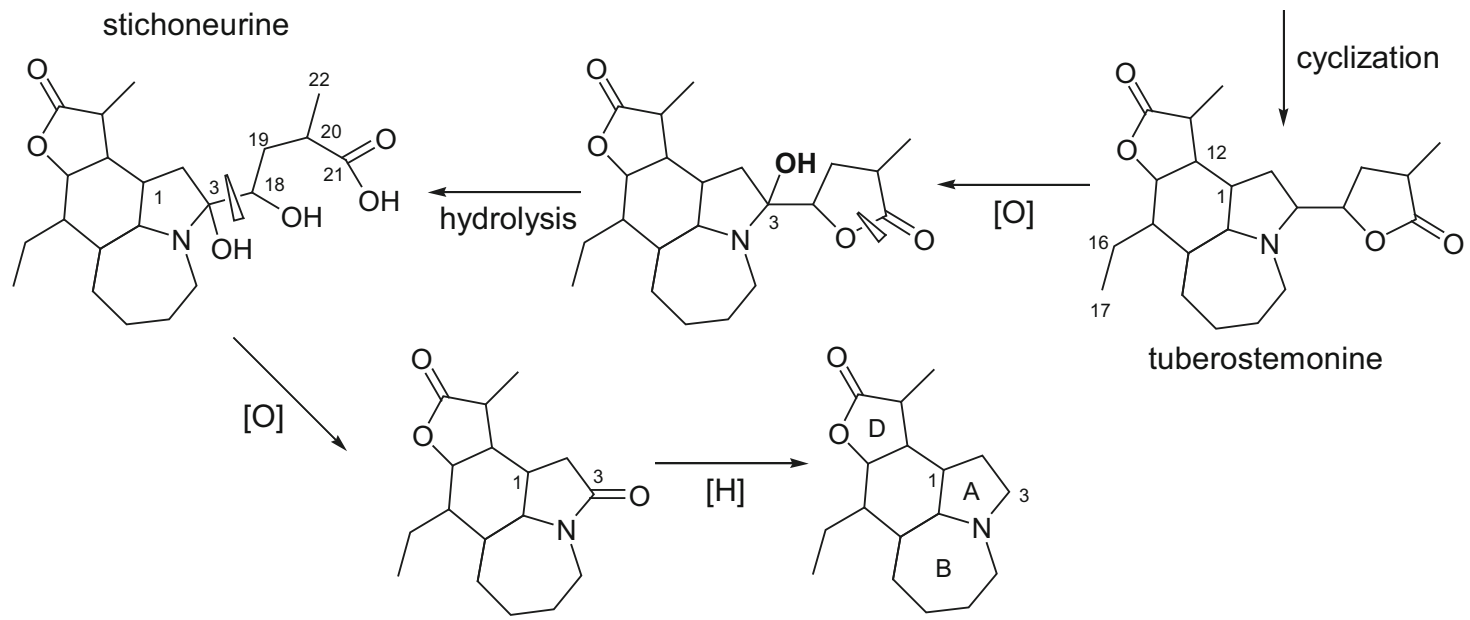

tuberostemonine

stenine

Fig. 4 Plausible biogenetic pathway leading to elimination of lactone ring C (redrawn from Lai et al. 2013)

stereoisomers (53-65) and dehydro derivatives (e.g. 66-78). Additional variation is created by various oxygenations leading to hydroxy groups and oxygenbridges, especially attached at the positions $C-1, C-9$, and $C-9 \mathrm{a}$, as well as to the formation of $N$-oxytuberostemonine (79). The unique structural feature of the stemoxazolidinones A-F is generated by an oxazolidin-2-one ring fused with $C$-1-C-9a $(\mathbf{8 3}, \mathbf{8 4}$, 115-117) or with $C-9-C-9$ a (85) (Hitotsuyanagi et al. 2011). A modification of the basic skeleton was reported for tuberostemoenone (87), where the sixmembered ring of the tuberostemonines is contracted to a cyclopentene ring (Cui and Lin 1998). The shift of lactone ring $\mathrm{D}$ from $C-11-C-12$ to $C-12-C-1$, most likely produced by hydrolysis and a following relactonization of $\mathrm{C}$-14 with $\mathrm{OH}$-1, leads to oxotuberostemonine (88) ${ }^{1}$ (Kondo et al. 1954; Huber et al. 1968), the related tuberostemolines A, B (101, 136) (Gao et al. 2014), and to stemona-lactam M (102) (Hitotsuyanagi et al. 2013a).

\footnotetext{
${ }^{1}$ A corresponding structure with a saturated $C-9-C-9$ a bond was also reported as oxotuberostemonine A (Gao et al. 2014).
}

\section{Formation of macro-rings}

Oxidative ring cleavages between $C-1$ and $C-9$ a or between $C-9$ and $C-9$ a were considered to generate nine- (89-96) or eleven-membered macro-lactam rings $(\mathbf{9 7 - 1 0 2}, \mathbf{1 3 6})$, respectively. Stemona-lactam G (100) is produced by a transannular hemiacetal linkage between the $C$ - 1 hydroxyl and $C-9$ ketone carbonyl group (Hitotsuyanagi et al. 2007a). A series of derivatives is characterized by a six membered piperidone ring A (105-113) from which tuberostemoninol (106) can be regarded as possible biogenetic precursor for derivatives with macro-rings. Tuberostemoninol (106) was also suggested to be involved in the formation of stemona-lactams K (103) and L (104), showing a rare skeleton with an unusual pyrido[1,2a] azonine system incorporating lactone ring $\mathrm{C}$ (Hitotsuyanagi et al. 2010). In this case the formation of the nine-membered ring can be explained by ring cleavages between $C-1$ and $C$-9a and between $C$-9a and $N$, combined with an additional $C-1-C-9$ linkage. Tuberostemonone (89) was suggested to be the precursor of stemosessifoine (114) by forming a linkage between $C-12$ and $C$-9a (Guo et al. 2008). As in the stemoninine-type derivatives additional 


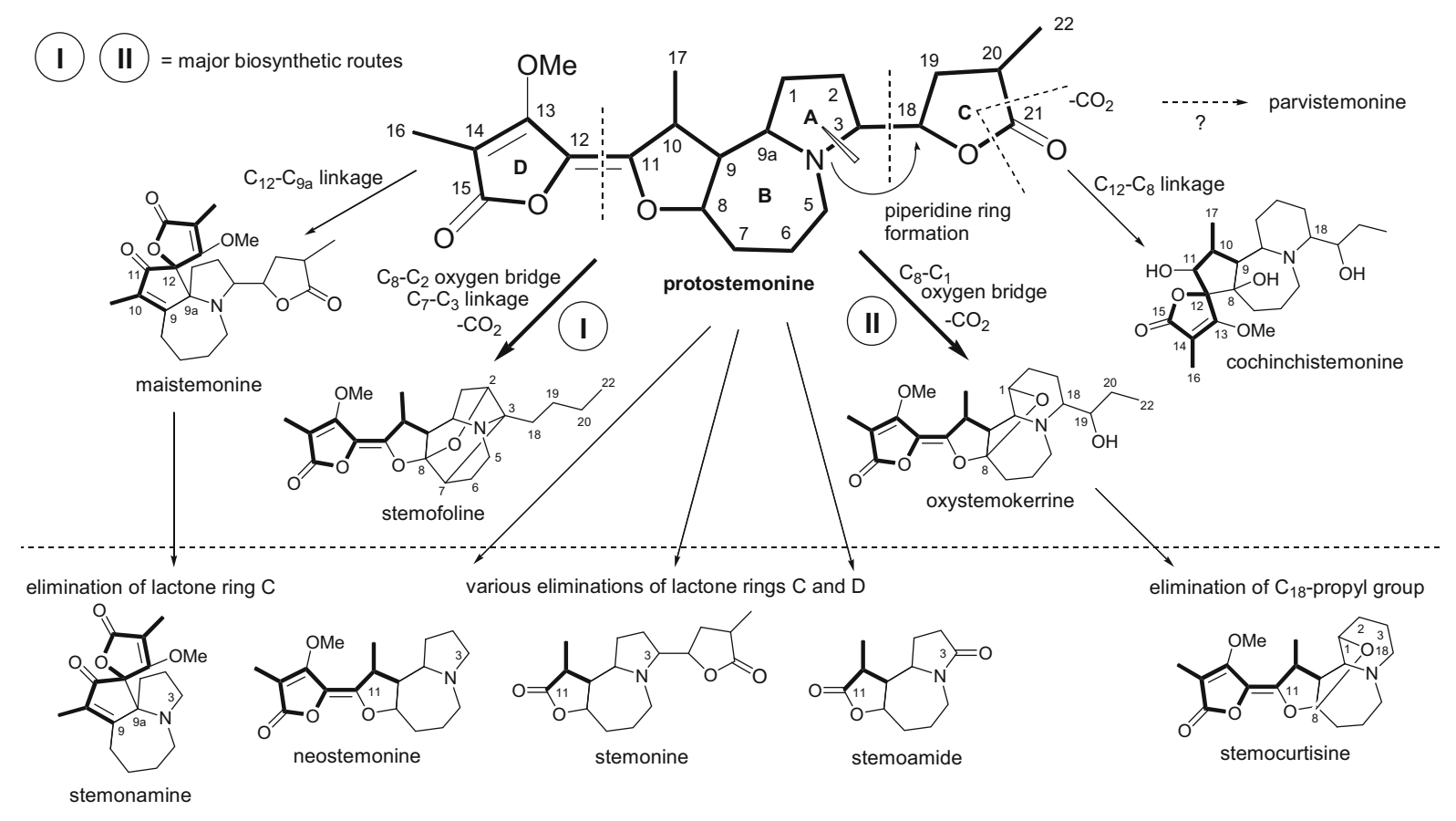

Fig. 5 Proposed transformations of protostemonine derived structures

structural variation in the tuberostemonines is created by the elimination of lactone ring $\mathrm{C}$ (127-136).

Regarding the literature data and results from our broad-based phytochemical analyses it became apparent that actually only few derivatives listed in Table 2 were detected in chromatographic comparisons. Most likely, this discrepancy can be explained both by the formation of artifacts and by the low concentrations of some derivatives which were not detectable in chromatographic systems, especially when only small quantities of plant material were extracted. It has already been pointed out previously that especially bisdehydro-derivatives (e.g. 66-76) may be regarded as artifacts produced by extraction or fractionation (Greger 2006). This was also underlined in subsequent investigations (Jiang et al. 2006b; Schinnerl et al. 2007; Kongkiatpaiboon et al. 2011; But et al. 2012). On the other hand, regarding the relatively mild extraction conditions, isolation, and purification procedures, there was no indication for the formation of artifacts in the highly oxidized stemonatuberones A-C (91-93) and stemonatuberonol A (95) (Yue et al. 2014).

\section{Protostemonines}

The protostemonine derivatives are characterized by a methyl group $(C-17)$ attached at $C-10$ and the formation of a mostly unsaturated lactone ring D linked to $C$ 11 by a double bond. As shown in Fig. 5 two major transformations (I, II) within the pyrroloazepine nucleus lead either to stemofoline- or to oxystemokerrine-type derivatives. The complex cage-type structure of stemofoline (160) is produced by an oxygen bridge between $C-8$ and $C-2$ accompanied by an additional $C-C$ linkage between $C-7$ and $C-3$, whereas the structure of oxystemokerrine (186) is characterized by transformation of the pyrrolidine ring A into a piperidine ring (Kaltenegger et al. 2003) containing an oxygen bridge between $C-8$ and $C-1$. Both routes show a common trend in hydrolyzing lactone ring $\mathrm{C}$ and splitting off $C-21$ by decarboxylation. As in the stichoneurine derivatives structural variation is also created by the loss of lactone ring C (194-209). However, in contrast to the stichoneurines, additional modification is generated by elimination of lactone ring D (210-215) or even of both rings in stemoamide (214) and parvistemoamide (215). Regarding the loss of the open carbon chains, derived from lactone ring $\mathrm{C}$, it is interesting to note, that only the propyl rest of the 


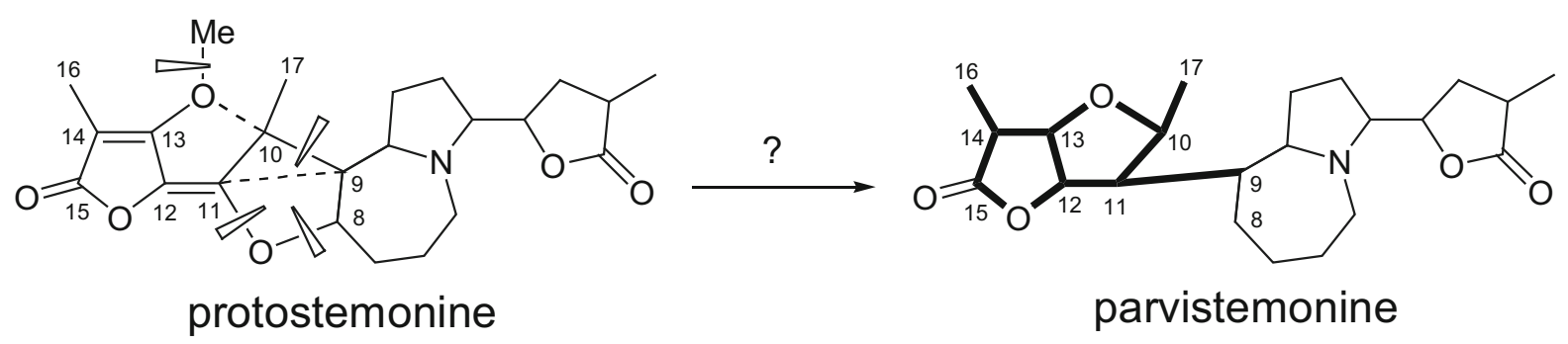

Fig. 6 Hypothetical alternative formation of parvistemonine from protostemonine

pyridoazepines 191-193 was shown to be eliminated. The corresponding methyl substituent in methylstemofoline (182) appears to be produced in a different way by chain-shortening (Table 3 ). Similar to the stichoneurines, $C-12$ of lactone ring $\mathrm{D}$ can also be linked to $C-9 \mathrm{a}$ or to $C-8$, leading either to the maistemonine- or the cochinchistemonine-type derivatives, respectively. However, the structures of both types clearly differ from the stichoneurines by the formation of a spiro system (Fig. 5). Although the structure of parvistemonine (37) shows close relations to the stichoneurine skeleton (Fig. 3), its exclusive occurrence in Stemona species, wich are otherwise characterized by protostemonine derivatives, let also expect an alternative formation (Fig. 6).

Protostemonine (137) itself was shown to occur with different oxidations (141-143, 159) and dehydro derivatives $(140,144-146,151,152,159)$. Of special interest are the different oxygen bridges between $C-8$ and $C-1$ in oxyprotostemonine (141) and between $C-6$ and $C-2$ in neostemofoline (159), indicating possible biosynthetic connections to the major components oxystemokerrine (186) or stemofoline (160), respectively. Protostemodiol (147) was assumed to be a cleavage product formed by hydrolyzation, the same as in neostemodiol (197) (Tang et al. 2008).

\section{Stemofoline-type derivatives (I)}

Structural variation in the protostemonines is mainly created by stemofoline-type derivatives (160-182). Apart from the formation of isomers $(\mathbf{1 6 1}, \mathbf{1 7 0}, \mathbf{1 7 1}$ ?, 174) diversification is primarily build up in the open butyl side chain attached at $C$-3. Hydroxylation was mainly found at $C-2^{\prime}(C-19)(\mathbf{1 6 4}, \mathbf{1 6 5}, \mathbf{1 6 9}, \mathbf{1 8 0})$, but also at $C-1^{\prime}(C-18)(\mathbf{1 6 3}), C-3^{\prime}(C-20)(\mathbf{1 7 6}, \mathbf{1 7 7})$, and at the terminal $C-4^{\prime}(C-22)(\mathbf{1 6 7}, \mathbf{1 7 1}$ ?). The double bonds between $C-1^{\prime}$ and $C-2^{\prime}$ in didehydrostemofoline
(173) and in closely related derivatives (174-178) are most likely formed by dehydration. Additional oxidations lead to hydroxy groups in ring $\mathrm{B}$ at $C-6(6 \beta$ hydroxystemofoline (162)) and $C-8$ (stemoburkilline (181)), and in ring D at $C$-16 (16-hydroxystemofoline (172), as well as to the formation of the $N$-oxide 175. In stemofolinoside (178) a $\beta$-glucopyranosyl moiety is attached to $C-5$, representing the first glycosylated Stemona alkaloid (Sastraruji et al. 2005).

\section{Oxystemokerrine-type derivatives (II)}

Only few modifications are known from the oxystemokerrine-type derivatives characterized by a pyridoazepin basic structure. Apart from isomerism (188) and the loss of the propyl side chain (191-193) further variations are created by $N$-oxidation $(\mathbf{1 8 7}, \mathbf{1 9 2})$, the cleavage of the azepan ring B (193), and the elimination of lactone ring D in oxstemokerrilactone (212) (Wang et al. 2007b). The closely related stemokerrine (183) deviates by a double bond between $C-7$ and $C-8$ and shows further modifications by $N$-oxidation (184, $\mathbf{1 8 5}$ ) and methoxylation of the propyl side chain (185). Stemokerrine (183) was proposed to be the biogenetic precursor of cochinchistemonine (189) and cochinchistemoninone (190) by opening the ether bond between $C-8$ and $C-11$ and forming a linkage between $C-8$ and $C-12$ (Lin et al. 2007a; Wang et al. 2007b).

\section{Bioactivities}

Antitussive activity

As reviewed previously, the antitussive activity of the tuberous roots of Stemona tuberosa, S. japonica, and S. sessilifolia, called Baibu in Chinese, was at all times of special importance in traditional Chinese medicine 
(TCM) (Greger 2006; But et al. 2012). Using the citric acid-induced guinea pig cough model Chung et al. (2003) demonstrated for the first time significant antitussive activity for the two tuberostemonine-type derivatives neotuberostemonine (59) and neostenine (129) isolated from $S$. tuberosa. The potency of these compounds was comparable to codeine but not involving opioid receptors in guinea pigs. Taking into account the chemical variation within the $S$. tuberosa group Xu et al. (2006) investigated plant samples originating from different provinces of China and found that the different alkaloid profiles could be grouped into four types represented by tuberostemonine (52), neotuberostemonine (59), stemoninine (21), or croomine (1) as major components. In spite of these chemical differences all samples demonstrated different degrees of antitussive properties, suggesting that besides tuberostemonine- $(\mathbf{5 2}, \mathbf{5 9}, \mathbf{1 2 9})$ or stemoninine-type structures (21) alkaloids with a croomine skeleton (1) can also contribute to the antitussive properties. Using the same test system Lin et al. (2006) reported on significant antitussive activity of bisdehydrostemoninine (28). However, it exhibited markedly lower potency in cough suppression than neotuberostemonine (59).

After intraperitoneal and oral administration a dose-dependent inhibition was also described for the stemoninine-type derivatives stemoninine (21) and stemoninoamide (44), suggesting that both compounds have a good oral absorption (Lin et al. 2008a). Similarly, no significant difference in activity between the two routes of application was determined for croomine (1) (Lin et al. 2008b). In a more detailed study the intestinal absorption of neotuberostemonine (59) and neostenine (129) was investigated using a Caco-2 monolayer model. Both compounds exhibited good absorptive permeability and thus are likely to be orally active components. Furthermore, both alkaloids were identified to be the substrates of P-glycoprotein (Leung et al. 2006). Oral absorption and antitussive activities were compared between the stereoisomers tuberostemonine (52), neotuberostemonine (59), and tuberostemonine $\mathrm{H}(\mathbf{6 0})$. All three isomers exhibited dose-dependent inhibitory effects after intraperitoneal administration. Tuberostemonine (52) itself was shown to have the same potency via both oral and intraperitoneal dosing, whereas neotuberostemonine (59) exhibited significantly lower, and tuberostemonine $\mathrm{H}(\mathbf{6 0})$ no oral activity. The activity of a further isomer, tuberostemonine $\mathbf{J}(\mathbf{6 1})$, could not be tested due to scarce material, but it demonstrated a moderate permeability in Caco- 2 monolayer cells. The differences in transport mechanisms and potencies of the antitussive activity via different administrative routes were discussed as a result of various stereo configurations (Zhou et al. 2009).

A follow-up study confirmed the antitussive effects of the four major alkaloids croomine (1), stemoninine (21), tuberostemonine (52), and neotuberostemonine (59) of $S$. tuberosa when their potency was compared at a fixed dosage. Moreover, it was shown that they actually do not express their effects through the same mechanisms. Whereas the stichoneurine derivatives 21, 52, and 59 acted on the peripheral cough reflex pathway, croomine (1) was shown to have central depressant effects. This may partly account for the adverse side effects previously reported for using corresponding plant samples (Xu et al. 2010). However, all results mentioned above disclosed only chemicals responsible for the antitussive activity of $S$. tuberosa but not for that of $S$. japonica and $S$. sessilifolia, the other two representatives of the Chinese drug Baibu, whose chemical constituents differ greatly by the accumulation of protostemonine derivatives. Yang et al. (2009) closely analyzed the alkaloid composition of $S$. sessilifolia and investigated the antitussive activity of the main constituents protostemonine (137), maistemonine (153), and the croomine-type derivative stemospironine (4) also using the citric acid-induced cough model. All three alkaloids showed significant antitussive activity following peripheral administration. Stemonamine (206), which is structurally closely related to $\mathbf{1 5 3}$, also showed activity after administration through a single intracerebroventricular injection. Due to the considerable interest in the synthesis of structurally diverse analogues of biologically active compounds Frankowski et al. (2008) elaborated an efficient synthetic route for the exploration of tuberostemonine-type analogues with a tricyclic core. In a following study they reported on the synthesis and receptor profiling of these analogues which reveal a potent class of sigma ligands (Frankowski et al. 2011).

Insecticidal activity

On the basis of chronic feeding bioassays with neonate larvae of the polyphagous pest insect Spodoptera 
littoralis (Lepidoptera, Noctuidae) reared on artificial diet the leaf and root extract of Stemona collinsiae displayed very high insect toxicity. By contrast, the extracts from $S$. tuberosa demonstrated low activity in roots and no activity in leaves (Brem et al. 2002). In accordance with previous findings with the diamondback moth Plutella xylostella (Jiwajinda et al. 2001) this strong activity of $S$. collinsiae could be attributed to didehydrostemofoline (173), whose $\mathrm{LC}_{50}$ value at $0.84 \mathrm{ppm}$ was higher than that of the co-occurring stemofoline (160) with $2.04 \mathrm{ppm}$ and the closely related 2'-hydroxystemofoline (164) with $30.33 \mathrm{ppm}$. Clearly different was the activity of tuberostemonine (52) from the roots of $S$. tuberosa, exhibiting a $\mathrm{LC}_{50}$ value at $>500 \mathrm{ppm}$. In addition to the activities after oral administration the crude extracts of $S$. tuberosa and $S$. collinsiae also showed strong feeding inhibitory properties against fifth instar larvae in a leaf disk choice test. In view of the low toxicity of $S$. tuberosa, the high repellent effect of the root extract was surprising. Further experiments led to the conclusion that tuberostemonine (52) acts as a potent repellent without toxic effects (Brem et al. 2002). In view of these results it can be assumed that the recently published significant insecticidal activity of the root extract of $S$. collinsiae against the fly Parasacrophaga ruficornis (Sakulpanich et al. 2017) can also be attributed to didehydrostemofoline (173), which was shown to be the main component of all samples of $S$. collinsiae collected in Thailand (Kongkiatpaiboon et al. 2011).

Comparing the insecticidal properties of the crude extracts of four other Stemona species, S. curtisii and S. cochinchinensis proved to be most active, whereas S. kerrii and S. aphylla (published as unknown species HG 915) clearly showed less activity. The high activity of the first two species was attributed to stemofoline (160), and was assumed to be caused by neurotoxic interactions resulting in uncontrolled hyperactivity of larvae. In contrast to this excitatory effect causing immediate death, the extracts of the two latter species displayed a different mode of action characterized by a delayed entrance of death accompanied by softening of the larval bodies. The latter phenomenon has already been described for stemospironine (4) (Sakata et al. 1978). The main causative agents for $S$. kerrii were identified as the pyridoazepine oxystemokerrine (186) with a $\mathrm{LC}_{50}$ value at $5.9 \mathrm{ppm}$ and the pyrroloazepine dehydroprotostemonine (140) at $6.1 \mathrm{ppm}$ (Kaltenegger et al. 2003). In view of the observed infraspecific chemical variation in S. curtisii (Schinnerl et al. 2007; Kongkiatpaiboon et al. 2011), ten root samples collected from various localities in Thailand were analyzed by HPLC and the four major components stemofoline (160), stemocurtisine (191), oxystemokerrine (186), and stemocurtisinol (188) were investigated for their insecticidal activities. In accordance with previous results the highest activity was determined for 160 (Kongkiatpaiboon et al. 2013).

The stemofolines $\mathbf{1 6 0}$ and $\mathbf{1 7 3}$ were shown to display rapid reactions leading to complete cessation of food intake. Since this reaction was accompanied by vomiting and trembling, it was interpreted as an expression of toxicity and not simply as a feeding inhibition (Brem et al. 2002). The strong activity of stemofoline (160) was first detected in the leaf extract of S. japonica, where its toxicity was shown to be much higher than the co-occurring croomine-type derivative stemospironine (4), showing a different mode of action (Sakata et al. 1978). Similar to commercialized neonicotinoids the mode of action of $\mathbf{1 6 0}$ was determined to be agonist at insect nicotinic acetylcholine receptors by using electrophysiological in vitro tests and by in vivo screenings against relevant agricultural insect pests (Tang et al. 2008). It was found that $\mathbf{1 6 0}$ and the structurally related derivatives 6 $\beta$-hydroxystemofoline (162), 16-hydroxystemofoline (172), and neostemofoline (159) tested in vitro are active on isolated neurons from the pest insect Heliothis virescens. For the 6-hydroxy derivative $\mathbf{1 6 2}$ an $\mathrm{EC}_{50}$ value of $157 \mathrm{nmol}$ indicated lower potency than 160 with $50 \mathrm{nmol}$, whereas hydroxylation at the lactone ring D in $\mathbf{1 7 2}$ showed an even stronger effect than 160 with an $\mathrm{EC}_{50}$ value at $12 \mathrm{nmol}$. By contrast, 13-demethoxy-11S,12R-dihydroprotostemonine (149) (later also named isostemocochinin (Yi et al. 2015)) and protostemodiol (147) were shown to act as antagonists. This study has shown that the cage-type moiety of stemofolines is pivotal to their insecticidal activity (Fig. 7). The half-cage derivative $\mathbf{1 5 9}$ is a partial agonist due to the significant changes in the cage moiety (Tang et al. 2008). Stemofoline derivatives with their high insecticidal activity already inspired as lead structures the development of synthetic cyanotropanes, a novel class of commercial insecticides interacting at the nicotinic acetylcholine receptor (Lind et al. 2002). 
Fig. 7 Various bioactivities of stemofoline (160) and structurally related derivatives

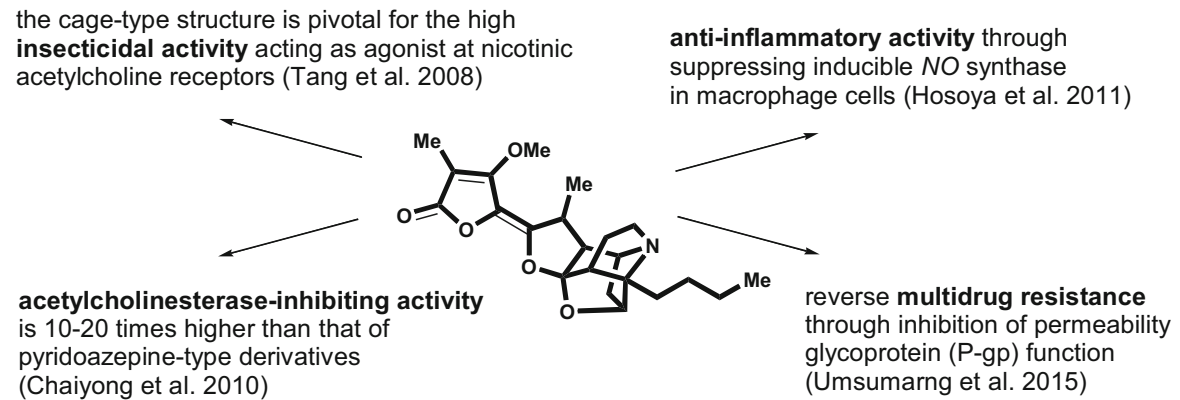

insecticidal activity acting as agonist at nicotinic anti-inflammatory activity through suppressing inducible NO synthase

in macrophage cells (Hosoya et al. 2011) pyridoazepine-type derivatives (Chaiyong et al. 2010)
Structure-activity relationships also became apparent within the pyridoazepine derivatives displaying the highest activity for oxystemokerrine (186), containing an oxygen bridge between $C-1$ and $C-8$, with a $\mathrm{LC}_{50}$ value at $5.9 \mathrm{ppm}$. $\mathrm{N}$-oxidation in oxystemokerrine- $\mathrm{N}$ oxide (187) or replacement of the oxygen bridge by a double bond in stemokerrine (183) diminished activities to $\mathrm{LC}_{50}$ values at $12.5 \mathrm{ppm}$ for $\mathbf{1 8 7}$ and $58 \mathrm{ppm}$ for 183. A significant decrease of toxicity, however, was caused by the loss of the open butyl side chain in stemocurtisine (= pyridostemin) (191) $\quad\left(\mathrm{LC}_{50-}\right.$ $=149 \mathrm{ppm})$ or its $O$-methylation in methoxystemokerrine-N-oxide (185) $\left(\mathrm{LC}_{50}=>100 \mathrm{ppm}\right)$. Somewhat different activities against mosquito larvae (Anopheles minimus) were reported for stemocurtisinol (188), a stereoisomer of 186, with $\mathrm{LC}_{50}$-values at $39 \mathrm{ppm}$ and for 191 at $18 \mathrm{ppm}$ (Mungkornasawakul et al. 2004a). Furthermore, comparing all results mentioned above, it became apparent that the double bond between $C-11$ and $C-12$ of lactone ring $\mathrm{D}$, characteristic for many protostemonine derivatives (Table 3), also plays a crucial role. It is missing in stemocochinine (148) and parvistemonine (37), where it led to a strong decrease of activity with $\mathrm{LC}_{50}$ values at $170 \mathrm{ppm}$ for $\mathbf{1 4 8}$ or even $>200$ ppm for 37 (Kaltenegger et al. 2003).

\section{Nematicidal activity}

In a more recent investigation twenty-five Stemona alkaloids were isolated from the roots of S. parviflora, collected in Hainan island in China, and tested for their activity against the nematode Panagrellus redivivus. The activity of all isolated compounds was evaluated in a lethality assay showing $\mathrm{IC}_{50}$ values at $42.5,1.95$, and $76.4 \mu \mathrm{mol}$ for $3 \beta$ - $n$-butylstemonamine (157), protostemonamide (194), and $(+)$ oxystemofoline (167), respectively, comparable to the positive control albendazole with $67.2 \mu \mathrm{mol}$. However, protostemonine (137) and stemofoline (160) showed nematicidal activity superior to that of the control with $\mathrm{IC}_{50}$ values at 0.10 and $0.45 \mu \mathrm{mol}$, respectively (Huang et al. 2016). Nematicidal activity was recently also reported for the crude extract of $S$. mairei, which is consistent with the presence of protostemonine (137) as major constituent (Chen et al. 2018).

Acetylcholinesterase inhibition

Since the insecticidal properties of Stemona alkaloids were found to be associated with acetylcholinesterase (AChE) inhibition various derivatives were screened for their activities in bioassays using huperzine A, physostigmine or galanthamine as positive controls. Wang et al. (2007a) reported for the first time on AChE-inhibiting activity of Stemona alkaloids. From the diastereoisomeric tuberostemonine-type alkaloids sessilistemonamines A-C $(\mathbf{1 1 9}, \mathbf{1 2 1}, \mathbf{1 2 0})$ only A (119) and B (121) were found to be moderately active with $\mathrm{IC}_{50}$ values at 68.8 and $17.1 \mu \mathrm{mol}$, respectively, whereas C (120) did not show any activity.

Five naturally occurring stemofoline-type alkaloids $(166,173,176,177,182)$ together with the two synthesised stereoisomeric derivatives $\left(3^{\prime} R\right)$-hydroxystemofoline and (11E)-methylstemofoline were screened for their AChE-inhibiting properties by TLC bioautography. It was found that didehydrostemofoline (173) and (3'S)-hydroxystemofoline (166) were clearly the most active (Baird et al. 2009). By contrast, the pyridoazepine alkaloids stemocurtisinol (188), stemocurtisine (191) and four synthetic analogues as well as the pyrroloazepine oxyprotostemonine (141) where shown to be 10-20 times less active (Chaiyong et al. 2010). Starting with the highly active $\mathbf{1 7 3}$ the same working group prepared a number of related analogues with modifications in the $C-3$ butyl side chain and screened their AChE inhibitory 
activities. They found that $\left(1^{\prime} R\right)$ hydroxystemofoline (163) was also very active, even slightly more than 173 (Fig. 7) (Sastraruji et al. 2010). In a follow-up study thirty-two stemofoline analogues were prepared from 173, comprising several novel $C$-3 side-chain amino, carbamate, triazole and oxazole derivatives. Compared to earlier results, this study showed that in general the amine derivatives were more active than the previously reported alcohol derivatives. Preliminary molecular docking studies indicated that derivatives with small side chains bind in a differnt way to the binding sites of AChE than those with longer side chains. Using the TLC bioautographic method, didehydrostemofoline (173) was shown to be the most active of the tested compounds against human (h) and electric eel (ee) AChE. However, the activity was significantly less than that of the posititive control galanthamine (Sastraruji et al. 2012).

Comparing the AChE-inhibiting properties of seven stichoneurine derivatives, isolated from the roots of Stichoneuron halabalensis, significant activity against hAChE was reported for stemoninine (21) and bisdehydrostemoninine $\mathrm{A}(\mathbf{3 4})$ with $\mathrm{IC}_{50}$ values at 3.74 and $5.52 \mu \mathrm{mol}$, respectively. Stichoneurine E (24) was shown to be the only derivative with high activity against eeAChE with $5.90 \mu \mathrm{mol}$. All other compounds were less active than the positive control galanthamine with $0.54 \mu \mathrm{mol}$ against hAChE and $0.32 \mu \mathrm{mol}$ against eeAChE (Ramli et al. 2013). Structure-activity relationship became apparent for four further stichoneurine derivatives, isolated from the roots of Stichoneuron caudatum, when tested against hAChE. The isomeric sessilistemonamines $\mathrm{E}$ (123) and $\mathrm{F}(\mathbf{1 2 2})$ exhibited significant activity for $\mathbf{1 2 3}$ with an $\mathrm{IC}_{50}$ value at $9.1 \mu \mathrm{mol}$, but no activity ( $>100 \mu \mathrm{mol})$ for 122. Moreover, a modest activity at $71.5 \mu \mathrm{mol}$ was determined for stichoneurine $\mathrm{F}(\mathbf{4 0})$, while the closely related stichoneurine G (41) was not active at $100 \mu \mathrm{mol}$, indicating an adverse effect by the additional $C$-9 hydroxy group (Ramli et al. 2014).

A bioactivity-guided chromatographic fractionation of the root extract of S. tuberosa (erroneously published as $S$. sessilifolia) led to the isolation of five stichoneurine derivatives, from which stenine (127) and especially stenine $\mathrm{B}^{2}(\mathbf{1 2 8})$ exhibited strong

\footnotetext{
${ }^{2}$ The same structure has also been reported for sessilifoline B (Qian and Zhan 2007), however, the spectral data were not identical with those of stenine B (128) (Lai et al. 2013).
}

activity with $\mathrm{IC}_{50}$ values at 19.8 and $2.1 \mu \mathrm{mol}$, respectively, while neotuberostemonine (59), neostenine (129), and stenine A (130) showed only very weak activity. Since the compounds 127, 128, and 129 are stereoisomers, the observed differences in the inhibition of AChE could only be explained by different spatial configurations. Moreover, $\mathrm{N}$-oxidation in $\mathbf{1 3 0}$ appeared to be very disadvantaged for activity. A kinetic analysis of $\mathbf{1 2 8}$ indicated that its AChE inhibition was reversible and competitive. In addition, a docking program was applied to predict the binding modes of $\mathbf{1 2 8}$ into the huperzine A binding site of AChE. It was shown that $\mathbf{1 2 8}$ acts internally around the tryptamine 84 and has the same hydrogen bonding interactions with tyrosine 130 as huperzine A. Regarding the suggested role of AChE in the pathogenesis of Alzheimer's disease, stenine B (128) was considered as a new interesting drug candidate (Lai et al. 2013).

\section{Multidrug resistance reversing properties}

The development of multidrug resistance (MDR) is a major impediment to the chemotherapeutic treatment of many forms of human cancer. A major factor in this process is the overexpression of the "permeability glycoprotein “(P-gp) in tumor cells preventing sufficient accumulation of anticancer dugs thereby avoiding their cytotoxic or apoptotic effects. The ethanolic crude extract of Stemona aphylla (published as $S$. curtisii) was shown to modulate P-gp activity and was expected to be effective in the treatment of multidrugresistant cancers (Limtrakul et al. 2007). Stimulated by these findings a more detailed study aimed to obtain the MDR-reversing components of Stemona species. Bioassay-guided fractionation led to the isolation of oxystemokerrine (186) and stemocurtisine (191) from S. aphylla, and stemofoline (160) from S. burkillii. They were evaluated for synergistic growth inhibitory effect with cancer chemotherapeutic agents including vinblastine, paclitaxel, and doxorubicin of KB-V1 (multidrug resistance cervical carcinoma cell line) cells using verapamil as a comparative agent. Among the three alkaloids stemofoline (160) exhibited the most potent effect in vitro in the reversal of P-gpmediated MDR (Chanmahasathien et al. 2011a). In a following investigation it was shown that $\mathbf{1 6 0}$ could increase the accumulation and retention of radiolabeled drugs or fluorescent P-gp substrates in a dose- 
dependent manner and that it may interact directly with P-gp and inhibit P-gp activity, whereas it has no effect on P-gp expression (Chanmahasathien et al. 2011b). The inhibition of P-gp mediated MDR was later also examined in KB-V1 and K562/Adr (human leukemic) cell lines with twelve other stemofoline derivatives, including didehydrostemofoline (173) and eleven synthesised derivatives with different $\mathrm{OH}$ - and $\mathrm{N}$-substitutions in the $\mathrm{C}$-3 side-chain. The results demonstrated structure-activity relationships and revealed that $\mathbf{1 7 3}$ and two $\mathrm{N}$-substituted derivatives dramatically increased the intracellular accumulation and cytotoxicity of the antineoplastic drugs in the P-gp overexpressing KB-V1 and K562/Adr cell lines in vitro (Umsumarng et al. 2013). Since the mode of action of the stemofolines on P-gp inhibition was unclear a continuing study aimed to investigate whether the stemofolines can reverse MDR through the inhibition of P-gp function or expression in human MDR leucemic cells (K562/Adr), or both. Since the stemofolines did not alter the P-gp expression, as determined by Western blotting, it was concluded that they reverse MDR via the inhibition of P-gp function (Fig. 7) (Umsumarng et al. 2015). The same authors tested eight naturally occurring protostemonine derivatives for their MDR modulation activity. They found that the three stemofoline-type derivatives isostemofoline (161), didehydrostemofoline (173), and isodidehydrostemofoline (174), having a core caged ring structure with non-polar side chains, enhanced the chemotherapeutic sensitivity of MDR leukemic K562/Adr cells, which overexpressed P-gp. For pharmaceutical safety testing they were shown to be not toxic to normal human fibroblasts and peripheral blood mononuclear cells and did not induce hemolysis in either human or rat erythrocytes (Umsumarng et al. 2017). More recent results indicated that stemofolin (160) itself did not affect tumor growth, but was able to enhance the efficacy of doxorubicin in scid-beige mice bearing K562/Adr xenografts. Additionally, the combination therapy significantly reduced the Ki67proliferation marker and induced apoptosis (TUNEL) (Umsumarng et al. 2018).

\section{Anti-inflammatory activities}

The methanolic root extract of Stemona javanica showed anti-inflammatory activity as measured by inhibition of nitric oxide (NO) production in lipopolysaccharide (LPS)-stimulated J774.1 mouse macrophage-like cells. Bioassay-guided fractionation led to the isolation of two active compounds, the alkaloid stemofoline (160) and the stilbenoid stemanthrene $\mathrm{C}$. The inhibition mechanism of $\mathbf{1 6 0}$ was proposed to suppress inducible $N O$ synthase in the macrophage cells stimulated by LPS, whereas that of stemanthrene $\mathrm{C}$ was due to radical scavenging (Hosoya et al. 2011). The anti-inflammatory effect of the water extract of $S$. tuberosa was investigated in LPS-stimulated RAW 264.7 macrophages and in cigarette smoke-induced lung inflammation mouse models. The results suggested that the extract attenuated pulmonary inflammatory responses by inhibiting the expression of diverse inflammatory mediators. Preliminary HPLC-ESI-MS analysis let expect that stichoneurine derivatives with stemoninine (21) as major component together with croomine (1) were responsible for the anti-inflammatory effect (Lim et al. 2015). In a following study it was shown that tuberostemonine $\mathrm{N}$ (56) significantly inhibited the secretion of proinflammatory cytokines and chemokines in bronchoalveolar lavage fluid and decreased alveoli size in lung tissue (Jung et al. 2016). A reduction of LPS-induced $N O$ was also observed with a methanolic root extract of $S$. tuberosa in murine BV2 microglia cells. Bioactivity-guided fractionation led to the isolation of eight alkaloids from which bisdehydroneotuberostemonine (67), epi-bisdehydroneotuberostemonine $\mathrm{J}$ (72), and bisdehydrotuberostemonine (66) showed significant inhibitory effects (Lee et al. 2016).

A more recent study reported on protostemonine (137) as the main anti-inflammatory alkaloid from the roots of S. sessilifolia. The results demonstrated that 137 effectively attenuated LPS-induced inflammatory responses in vitro and in vivo. The effects were shown to be associated with the decreased phosphorylation of MAP (mitogen-activated protein) kinase and proteinkinase B and the reduced expression of pro-inflammatory mediators. The results suggested that $\mathbf{1 3 7}$ may be a potential therapeutic agent in the treatment of acute lung injury (Wu et al. 2018).

\section{Pharmacokinetics}

A rapid and selective UPLC-HDMS method (ultraperformance liquid chromatography coupled with 
high-resolution mass spectrometry) was developed to analyse the active alkaloids of Stemona extracts and their metabolites in rat plasma following oral administration. Twenty-nine compounds in "Radix Stemonae" extract and fourty-seven compounds in rat plasma samples were detected in a single injection within $21 \mathrm{~min}$, comprising croomine and stichoneurine derivatives. The study showed that hydroxylation, hydration, reduction, and change of alkenes to dihydrodiol were the crucial metabolic transformation pathways (Dong et al. 2012). An UPLC-QTOF (quadrupole time-of-flight)-HDMS method was successfully applied to investigate the pharmacokinetics of croomine (1), neotuberostemonine (59), and tuberostemonine (52) after oral administration of "Radix Stemonae" extract. The extract was rapidly distributed and then eliminated from rat plasma. The biodistribution of $\mathbf{5 9}$ and $\mathbf{5 2}$ showed higher levels in liver and lung. Croomine (1) was detected in brain and showed that it could cross the blood-brain barrier, indicating that it has an antitussive effect by acting on the central nervous system. By contrast, neotuberostemonine (59) and tuberostemonine (52) were not detected in brain, demonstrating that they act at the peripheral cough reflex pathway (Sun et al. 2012). A rapid and sensitive LC-ESI-MS/MS (liquid chromatography/electrospray ionization tandem mass spectrometry) method was developed and validated for determining protostemonine (137) in rat plasma. After oral administration $\mathbf{1 3 7}$ was rapidly absorbed from the gastrointestinal tract and has shown dose-independent pharmacokinetic profiles. Moreover, a total of 10 metabolites were identified in rat urine. Hydrolysis and oxygenation were proposed to be the major metabolic pathway (Han et al. 2016).

\section{Miscellaneous properties}

The crude extract of $S$. tuberosa enhanced apoptosis of medullary thyroid cancer cells (MTC), whereas that of S. collinsiae only moderately increased the apoptotic effect (Rinner et al. 2004). In a following study four different extracts from $S$. tuberosa with $n$-hexane, dichloromethane, ethyl acetate, and methanol were examined for their antiproliferative effects in two MTC cell lines. Only the dichloromethane extract was shown to inhibit cell growth and viability in a dose dependent manner. Moreover, it also exhibited strong apoptotic effects. Chromatographic analyses let expect that croomine (1) and/or tuberostemonine-type derivatives are responsible for these activities ( $\mathrm{Li}$ et al. 2007b).

Phuwapraisirisan et al. (2006) investigated the effect of stemofoline-type alkaloids on the delay of parturation of Wistar rats. Since preliminary results suggested that they may block uterine contraction regulated by oxytocin released during last pregnancy, the oxytocin antagonistic effects of didehydrostemofoline (173) (published as asparagamine A), stemofoline (160) and $2^{\prime}$-hydroxystemofoline (164) were examined on delayed parturation in pregnant rats. The results showed that $\mathbf{1 7 3}$ significantly delayed parturation, while no delay was observed for 160 and 164. However, it could not be confirmed that parturation delayed by $\mathbf{1 7 3}$ is due to its competitive binding to oxytocin receptor.

Synthetic intermediates of stemonamide (207) were reported to inhibit in vitro activities of Pim-3 kinase, a protooncogene with serine/threonine kinase activity, and its related kinases. The alkaloids were also shown to inhibit cell proliferation of various human pancreatic, hepatocellular and colon cancer cell lines, and to induce apoptosis of human pancreatic cells in vitro. The results indicated that these compounds and related derivatives may be effective for the treatment of tumors of endoderm-derived organs, particularly the pancreas (Li et al. 2010).

The extract of $S$. tuberosa was tested for activity against neuroaminidase of H5N1 avian virus in silico. From eighty-one compounds, including Stemona alkaloids and stilbenoids, thirty-three were selected as possible lead structures according to toxicity tests and Lipinski's rule of five. In docking analysis croomine (1) exhibited a promising activity by interacting to the active site of H5N1 neuroaminidase (Manohar 2013).

Protostemonine (137) was shown to exhibit protective effects on LPS/D-galactosamine (GalN)-induced acute liver failure, a clinical syndrom with a very high mortality rate. It was also found that induction of the hepatic antioxidant enzyme HO-1 plays an important role in the hepatoprotective activity of 137. Moreover, the study has shown, that even at the highest utilized dosages 137 exhibited undetectible toxic effects on vital organs of mice (Cheng et al. 2015). 
Idiopathic pulmonary fibrosis (IPF) is the most common and lethal lung disease characterized by a progressive and irreversible decline in lung function. Xiang et al. (2016) investigated the effects of neotoberostemonine (59) on bleomycin (BLM)-induced lung fibrosis in mice and the underlying mechanism. The study revealed that $\mathbf{5 9}$ significantly ameliorated lung histopathological changes and decreased inflammatory cell counts in the bronchoalveolar lavage fluid. The results suggested that the protective effects of $\mathbf{5 9}$ for BLM-induced mice was equivalent to that of nintedanib, a new drug for IPF.

\section{Chemotaxonomy}

Stemona alkaloids represent a typical chemical character of the family Stemonaceae so far not detected in any other plant family. They are mainly accumulated in the tuberous roots of Stemona species, but were also isolated from leaves and stems and the non-tuberous roots and rhizomes of the two other genera of the family Stichoneuron and Croomia. With regard to the many new data it became obvious that in accordance with previous considerations the taxonomically complex S. tuberosa group can be clearly distinguished from the other Stemona species by the formation of stichoneurine alkaloids (Greger 2006; Zhou et al. 2006; Jiang et al. 2006a, b; Schinnerl et al. 2007; Kongkiatpaiboon et al. 2011; But et al. 2012) (Fig. 3). With the formation of stemoninine-type derivatives this biogenetic trend was also detected in the two closely interrelated Stichoneuron species $S$. caudatum (Schinnerl et al. 2005; Ramli et al. 2014) and $S$. halabalensis (Ramli et al. 2013). However, in contrast to Stemona species no tuberostemonine-type alkaloids were found, characterized by the $C-12-C-1$ cyclization. Instead, both species deviate by the formation of the rare $C-12-C-9$ a cyclization in the sessilistemonamines $\mathrm{F}$ and $\mathrm{E}(\mathbf{1 2 2}, \mathbf{1 2 3})$. It is noteworthy, that here no croomine derivatives (Table 1) were detected, which are otherwise widely distributed in the genera Stemona and Croomia. Hence, it is tempting to assume that pandanamine and pandamarilactonine, isolated from the rare Stichoneuron calcicola (Greger et al. 2009), represent possible precursors for the formation of the croomine skeleton (Fig. 2).

Within the $S$. tuberosa group distinct trends towards different isomers of tuberostemonine (52) together

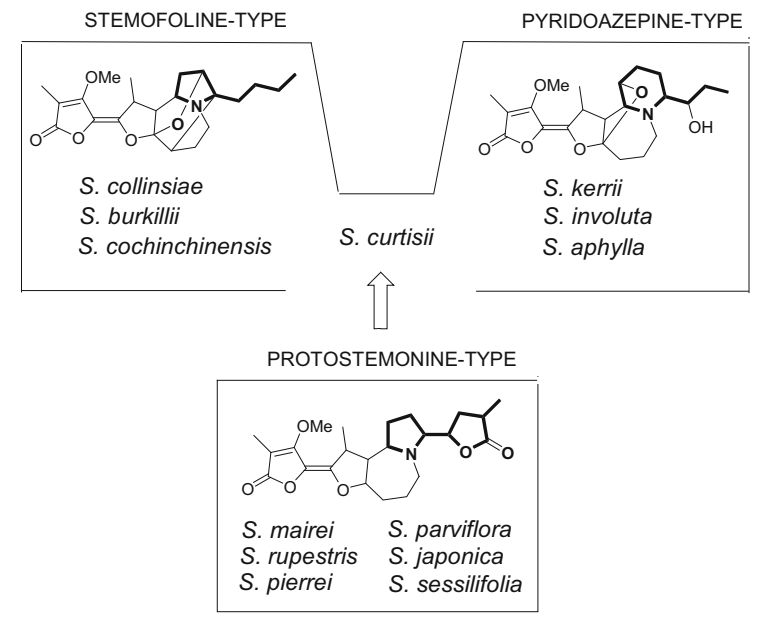

Fig. 8 Species grouping according to major accumulation trends towards different structural types of protostemonine derivatives in the roots

with floral characters contribute to a more natural species delimitation. In Thailand the accumulation of tuberostemonine A (53) distinguishes S. phyllantha from $S$. tuberosa, which is characterized by neotuberostemonine (59) and tuberostemonine $\mathrm{N}$ (56) (Schinnerl et al. 2007). This segregation was partly also underlined in 15 accessions recently investigated in southern China. The overview showed samples with distinct accumulation trends towards the abovementioned isomers as well as to a few intermediates. In addition, some accessions deviated by a predominance of stemoninine (21). Floral characters suggested here a closer relatioship to $S$. tuberosa (Chen et al. 2017).

The other Stemona species are characterized by protostemonine (137) derivatives (Fig. 5). Broadbased chromatographic comparisons of root extracts from 13 different species revealed characteristic accumulation trends either towards pyridoazepine- or stemofoline-type derivatives, which appeared to be of chemosystematic interest (Schinnerl et al. 2007; Kongkiatpaiboon et al. 2011) (Fig. 8). All samples of $S$. collinsiae collected in different localities of Thailand uniformly showed a predominance of didehydrostemofoline (173), indicating a species-specific chemical character. The closely related $S$. burkillii can be distinguished by an accumulation of stemofoline (160) (Mungkornasawakul et al. 2004b; Schinnerl et al. 2007). By contrast, the alkaloid profiles of $S$. kerrii were characterized by pyridoazepine derivatives, especially by a predominance of stemokerrine 
(183). This rare trend was also detected in S. saxorum (Wang et al. 2007c), which was regarded as a synonym of S. kerrii (Ji and Duyfjes 2000). Whereas these species were shown to be characterized by distinct accumulation trends, $S$. curtisii exhibited infraspecific chemical variability comprising samples accumulating either stemofoline- or pyridoazepine-type derivatives, as well as those with intermediate profiles (Schinnerl et al. 2007; Kongkiatpaiboon et al. 2011). In this connection it should be pointed out that $S$. curtisii, a species widely distributed in southern Thailand, also deviated by its chromosome number $2 n=13-16$, whereas the other Stemona species were shown to have the same chromosome number $2 n=14$ (Oginuma et al. 2001; Hartl and Kiehn 2004).

Pronounced chemical differences were also observed in $S$. aphylla, demonstrating infraspecific variability between different localities as well as different individuals within the same population. Generally, the results indicated a dominating trend towards accumulation of the pyridoazepine derivative oxystemokerrine (186), frequently accompanied by the structurally closely related stemocurtisine (191). This trend was also found in S. involuta supporting the suggested relationship with S. aphylla (Inthachub et al. 2010). Of some interest for chemotaxonomic conclusions was the variable formation of oxystemokerrine $\mathrm{N}$-oxide (187), which might be explained by different ways of sample preparation, as well as a general reduction of alkaloid formation in some accessions, showing only small amounts of protostemonine (137) accompanied by an accumulation of stilbenoids. A mutual accumulation of alkaloids or stilbenoids was also reported for different plant parts in one sample of S. curtisii (Schinnerl et al. 2007).

On the basis of the available results it became apparent that the alkaloid profiles of the Chinese species S. sessilifolia (Yang et al. 2009), S. japonica (Tang et al. 2008; Yi et al. 2015), S. parviflora (Huang et al. 2016), and S. mairei (Chen et al. 2018) deviate from the abovementioned species by a predominance of protostemonine (137) itself, accompanied by the structurally similar maistemonine (153), protostemonamide (194), stemonamide (207), and stemonine (211) together with corresponding isomers (Fig. 8). In this group of species stemofoline-type derivatives were shown to be accumulated only in the aerial parts of $S$. japonica (Sakata et al. 1978; Schinnerl et al. 2007; Tang et al. 2008), and were only found as minor components in the roots of $S$. parviflora (Huang et al. 2016) and S. mairei (Chen et al. 2018). However, no pyridoazepine alkaloids have been detected so far in the four species. Only small amounts of protostemonine were detected in S. pierrei and S. rupestris, two closely related endemic species of Thailand. With an additional accumulation of stilbenoids they formed a chemical trend similar to that found in two samples of S. aphylla, probably indicating a reduced enzymatic activity of alkaloid formation (Kostecki et al. 2004; Kongkiatpaiboon et al. 2011).

Considering the clear-cut chemical segregation of the $S$. tuberosa group from the other Stemona species by the formation of stichoneurine derivatives, the many reports on that type of alkaloids in S. sessilifolia appear to be the result of not properly identified plant material. In fact, Hitotsuyanagi et al. (2013a) later corrected the name $S$. sessilifolia to $S$. tuberosa in their papers based on subsequent DNA sequence analyses. In order to avoid confusion they renamed the originally published trivial names sessilifoliamides A-L to stemona-lactams A-L, and sessilifoliamine A to stemona-amine A (Table 2). With the shrubby habit and erect stem together with the whorled shortly petiolate or sessile leaves $S$. sessilifolia and the assumedly conspecific $S$. shandongensis ( $\mathrm{Li}$ and $\mathrm{Fu}$ 2007) can be distinguished from the other species which are characterized by a climbing habit and petiolate leaves. It is tempting to assume that the predominance of protostemonine (137) itself, accompanied only by structurally closely related derivatives, represents a more primitive biogenetic trend. Data from various DNA regions of different Stemona species, summarized and interpreted by But et al. (2012), largely supported the grouping outlined above (Fig. 8).

Acknowledgements Open access funding provided byUniversity of Vienna.

Open Access This article is distributed under the terms of the Creative Commons Attribution 4.0 International License (http:// creativecommons.org/licenses/by/4.0/), which permits unrestricted use, distribution, and reproduction in any medium, provided you give appropriate credit to the original author(s) and the source, provide a link to the Creative Commons license, and indicate if changes were made. 


\section{References}

Alibés R, Figueredo M (2009) Strategies for the synthesis of Stemona alkaloids. Eur J Org Chem 15:2421-2435

Asano N, Yamauchi T, Kagamifuchi K, Shimizu N, Takahashi S, Takatsuka H, Ikeda K, Kizu H, Chuakul W, Kettawan A, Okamoto T (2005) Iminosugar-producing Thai medicinal plants. J Nat Prod 68:1238-1242

Bacher M, Hofer O, Brader G, Vajrodaya S, Greger H (1999) Thapsakins: possible biogenetic intermediates towards insecticidal cyclopenta[b]benzofurans from Aglaia edulis. Phytochemistry 52:253-263

Baird MC, Pyne SG, Ung AT, Lie W, Sastraruji T, Jatisatienr A, Jatisatienr C, Dheeranupattana S, Lowlam J, Boonchalermkit S (2009) Semisynthesis and biological activity of stemofoline alkaloids. J Nat Prod 72:679-684

Brader G, Vajrodaya S, Greger H, Bacher M, Kalchhauser H, Hofer O (1998) Bisamides, lignans, triterpenes, and insecticidal cyclopenta[b]benzofurans from Aglaia species. J Nat Prod 61:1482-1490

Brem B, Seger C, Pacher T, Hofer O, Vajrodaya S, Greger H (2002) Feeding deterrence and contact toxicity of Stemona alkaloids-a source of potent natural insecticides. J Agric Food Chem 50:6383-6388

Brem B, Seger C, Pacher T, Hartl M, Hadacek F, Hofer O, Vajrodaya S, Greger H (2004) Antioxidant dehydrotocopherols as a new chemical character of Stemona species. Phytochemistry 65:2719-2729

Brito GA, Pirovani RV (2018) Stemoamide: total and formal synthesis. A review. Org Prep Proc Int 50:245-259

But PPH, Shaw PC, Lin G, Jiang RW, Xu YT (2012) Authentication and quality assesssment of the antitussive herb Baibu (Radix Stemonae). In: Shyur LF, Lau ASY (eds) Advances in Botanical Research, vol 62. Elsevier, Amsterdam

Cai XH, Luo XD (2007) Alkaloids from Stemona mairei. Planta Med 73:170-173

Chaiyong S, Jatisatienr A, Mungkornasawakul P, Sastraruji T, Pyne SG, Ung AT, Urathamakul T, Lie W (2010) Phytochemical investigations of Stemona curtisii and synthetic studies on stemocurtisine alkaloids. J Nat Prod 73:1833-1838

Chanmahasathien W, Ampasavate C, Greger H, Limtrakul P (2011a) Stemona alkaloids, from traditional Thai medicine, increase chemosensitivity via P-glycoprotein-mediated multidrug resistance. Phytomedicine 18:199-204

Chanmahasathien W, Ohnuma S, Ambudkar SV, Limtrakul P (2011b) Biochemical mechanism of modulation of human P-glycoprotein by stemofoline. Planta Med 77:1990-1995

Chen G, Brecker L, Felsinger S, Cai XH, Kongkiatpaiboon S, Schinnerl J (2017) Morphological and chemical variation of Stemona tuberosa from southern China-evidence for heterogeneity of this medicinal plant species. Plant Biol 19:835-842

Chen G, Brecker L, Sandler KM, Cai XH, Kongkiatpaiboon S, Valant-Vetschera K, Schinnerl J (2018) Phytochemical characterization of the Chinese endemic species Stemona mairei and five other Stemona species. Phytochem Lett 28:168-173
Cheng DL, Guo J, Chu TT, Röder E (1988) A study of Stemona alkaloids, III. Application of 2D-NMR spectroscopy in the structure determination of stemoninine. J Nat Prod 51:202-211

Cheng Z, Yue L, Zhao WH, Yang XH, Shu GW (2015) Protective effects of protostemonine on LPS/GalN-induced acute liver failure: roles of increased hepatic expression of heme oxygenase 1. Int Immunopharmacol 29:798-807

Chung HS, Hon PM, Lin G, But PPH, Dong H (2003) Antitussive activity of Stemona alkaloids from Stemona tuberosa. Planta Med 69:914-920

Cui YX, Lin WH (1998) 2D NMR studies on tuberostemoenone and tuberostemonone. Chin J Magn Res 15:515-520

Dong W, Wang P, Meng XC, Sun H, Zhang A, Wang WM, Dong H, Wang XJ (2012) Ultra-performance liquid chromatography-high-definition mass spectrometry analysis of constituents in the root of Radix Stemonae and those absorbed in blood after oral administration of the extract of the crude drug. Phytochem Anal 23:657-667

Dong JL, Yang ZD, Zhou SY, Yu HT, Yu HT, Yao XJ, Xue HY, Shu ZM (2017) Two Stemona alkaloids from Stemona sessilifolia (Miq.) Miq. Phytochem Lett 19:259-262

Edwards OE, Feniak G, Handa KL (1962) The alkaloids of Stemona sessilifolia. Can J Chem 40:455-462

Frankowski KJ, Neuenswander B, Aubé J (2008) Explorations of Stemona alkaloid-inspired analogues: skeletal modification and functional group diversification. J Comb Chem 10:721-725

Frankowski KJ, Setola V, Evans JM, Neuenswander B, Roth BL, Aubé J (2011) Synthesis and receptor profiling of Stemona alkaloid analogues reveal a potent class of sigma ligands. Proc Natl Acad Sci USA 108:6727-6732

Fukaya H, Hitotsuyanagi Y, Aoyagi Y, Shu Z, Komatsu K, Takeya K (2013) Absolute structures of stemona-lactam S and tuberostemospiroline, alkaloids from Stemona tuberosa. Chem Pharm Bull 61:1085-1089

Gao Y, Wang J, Zhang CF, Xu XH, Zhang M, Kong LY (2014) Seven new alkaloids from the roots of Stemona tuberosa. Tetrahedron 70:967-974

Ge F, Ke CQ, Tang W, Yang XZ, Tang CP, Qin GW, Xu RS, Li TX, Chen XW, Zuo JP, Ye Y (2007) Isolation of chlorogenic acids and their derivatives from Stemona japonica by preparative HPLC and evaluation of their anti-AIV (H5N1) activity in vitro. Phytochem Anal 18:213-218

Götz M, Bögri T, Gray AH, Strunz GM (1968) The structure of tuberostemonine. Tetrahedron 24:2631-2643

Greger H (2006) Structural relationships, distribution and biological activities of Stemona alkaloids. Planta Med 72:99-113

Greger H (2012) The diversity of Stemona stilbenoids as a result of storage and fungal infection. J Nat Prod 75:2261-2268

Greger H, Zechner G, Hofer O, Vajrodaya S (1996) Bioactive amides from Glycosmis species. J Nat Prod 59:1163-1168

Greger H, Schinnerl J, Vajrodaya S, Brecker L, Hofer O (2009) Pandanus alkaloids in Stemonaceae: finding of a plausible biogenetic origin of Stemona alkaloids. J Nat Prod 72:1708-1711

Guo A, Jin L, Deng ZW, Cai SQ, Guo SX, Lin WH (2008) New Stemona alkaloids from the roots of Stemona sessilifolia. Chem Biodivers 5:598-605 
Guo J, He HP, Li SL, Hua HM, Hao XJ (2010) A new alkaloid from the roots of Stemona tuberosa (Stemonaceae). Acta Bot Yunnanica 32:163-165

Han H, Yang L, Ding Y, Ji G, Zhang T (2016) Pharmacokinetics and metabolism profiles of protostemonine in rat by liquid chromatography combined with electrospray ionization tandem mass spectrometry. J Pharm Biomed Anal $117: 266-275$

Harada H, Irie H, Masaki N, Osaki K, Uyeo S (1967) The stereochemistry and absolute configuration of stenine and tuberostemonine. Chem Commun. https://doi.org/10.1039/ c19670000460

Hartl M, Kiehn M (2004) Chromosome numbers and other karyological data of four Stemona species (Stemonaceae) from Thailand. Blumea 49:457-460

Hitotsuyanagi Y, Hikita M, Oda T, Kakuta D, Fukaya H, Takeya K (2007a) Structures of four new alkaloids from Stemona sessilifolia. Tetrahedron 63:1008-1013

Hitotsuyanagi Y, Hikita M, Nakada K, Fukaya H, Takeya K (2007b) Sessilifoliamide I, a new alkaloid from Stemona sessilifolia. Heterocycles 71:2035-2040

Hitotsuyanagi Y, Takeda E, Fukaya H, Takeya K (2008) Sessilifoliamine A and sessilifoliamide J: new alkaloids from Stemona sessilifolia. Tetrahedron Lett 49:7376-7379

Hitotsuyanagi Y, Uemura G, Takeya K (2010) Sessilifoliamides $\mathrm{K}$ and L: new alkaloids from Stemona sessilifolia. Tetrahedron Lett 51:5694-5696

Hitotsuyanagi Y, Hikita M, Uemura G, Fukaya H, Takeya K (2011) Structures of stemoxazolidinones A-F, alkaloids from Stemona sessilifolia. Tetrahedron 67:455-461

Hitotsuyanagi Y, Fukaya H, Takeda E, Matsuda S, Saishu Y, Zhu S, Komatsu K, Takeya K (2013a) Structures of stemona-amine B and stemona-lactams M-R. Tetrahedron 69:6297-6304

Hitotsuyanagi Y, Shigemori G, Fukaya H, Hikita M, Zhu S, Komatsu K, Takeya K (2013b) Stemona-amines C-E, new alkaloids from Stemona tuberosa. Tetrahedron Lett 54:6995-6998

Hitotsuyanagi Y, Sekiya Y, Fukaya H, Park HS, Zhu S, Komatsu $\mathrm{K}$ (2016) Stemona-amines F and G, new alkaloids from Stemona tuberosa. Tetrahedron Lett 57:5746-5749

Hofer O, Greger H (2000) Sulfur-containing amides from Glycosmis species (Rutaceae). In: Herz W, Falk H, Kirby GW, Moore RE (eds) Progress in the chemistry of organic natural products. Springer, New York

Hosoya T, Yamasaki F, Nakata A, Rahman A, Kusumawati I, Zaini NC, Morita H (2011) Inhibitors of nitric oxide production from Stemona javanica. Planta Med 77:256-258

Hu JP, Yang DH, Lin WH, Cai SQ (2009) Alkaloids from the roots of Stemona tuberosa. Helv Chim Acta 92:2125-2133

Huang SZ, Kong FD, Ma QY, Guo ZK, Zhou LM, Wang Q, Dai HF, Zhao YX (2016) Nematicidal Stemona alkaloids from Stemona parviflora. J Nat Prod 79:2599-2605

Huber CP, Hall SR, Maslen EN (1968) The crystal structure of oxotuberostemonine. Tetrahedron Lett 4081-4084

Iizuka H, Irie H, Masaki N, Osaki K, Uyeo S (1973) X-ray crystallographic determination of the structure of stemonamine, a new alkaloid from Stemona japonica Miq.: isolation of isostemonamine. J Chem Soc Chem Comm. https://doi.org/10.1039/c39730000125
Inthachub P, Vajrodaya S, Duyfjes BEE (2009) Review of the genus Stichoneuron (Stemonaceae). Edinb J Bot 66:213-228

Inthachub P, Vajrodaya S, Duyfjes BEE (2010) Census of Stemona (Stemonaceae) in Thailand. Blumea 55:143-152

Irie H, Harada H, Ohno K, Mizutani T, Uyeo S (1970a) The structure of the alkaloid protostemonine. J Chem Soc D Chem Comm. https://doi.org/10.1039/c29700000268

Irie H, Masaki N, Ohno K, Osaki K, Taga T, Uyeo S (1970b) The crystal structure of a new alkaloid, stemofoline, from Stemona japonica. Chem Comm 17:1066

Ji ZH, Duyfjes BEE (2000) Stemonaceae. In: Wu ZY, Raven PH (eds) Flora of China, vol 24. Science Press, Beijing

Jiang RW, Hon PM, But PPH, Chung HS, Lin G, Ye WC, Mak TCW (2002) Isolation and stereochemistry of two new alkaloids from Stemona tuberosa. Tetrahedron 58:6705-6712

Jiang RW, Hon PM, Xu YT, Chan YM, Xu HX, Shaw PC, But PPH (2006a) Isolation and chemotaxonomic significance of tuberostemospironine-type alkaloids from Stemona tuberosa. Phytochemistry 67:52-57

Jiang RW, Hon PM, Zhou Y, Chan YM, Xu YT, Xu HX, Greger H, Shaw PC, But PPH (2006b) Alkaloids and chemical diversity of Stemona tuberosa. J Nat Prod 69:749-754

Jiwajinda S, Hirai N, Watanabe K, Santisopasri V, Chuengsamarnyart N, Koshimizu K, Ohigashi H (2001) Occurrence of the insecticidal 16,17-didehydro-16(E)stemofoline in Stemona collinsae. Phytochemistry 56:693-695

Jung KH, Kil YS, Jung J, Park S, Shin D, Lee K, Seo EK, Bae H (2016) Tuberostemonine N, an active compound isolated from Stemona tuberosa, suppresses cigarette smoke-induced sub-acute lung inflammation in mice. Phytomedicine 23:79-86

Kakuta D, Hitotsuyanagi Y, Matsuura N, Fukaya H, Takeya K (2003) Structures of new alkaloids sessilifoliamides A-D from Stemona sessilifolia. Tetrahedron 59:7779-7786

Kaltenegger E, Brem B, Mereiter K, Kalchhauser H, Kählig H, Hofer O, Vajrodaya S, Greger H (2003) Insecticidal pyrido[1,2- $a$ ]azepine alkaloids and related derivatives from Stemona species. Phytochemistry 63:803-816

Ke CQ, He ZS, Yang YP, Ye Y (2003) A novel alkaloid from Stemona parviflora. Chin Chem Lett 14:173-175

Kil YS, Han AR, Seo EK (2014) Tuberostemonin O from the roots of Stemona tuberosa. Bull Korean Chem Soc 35:1891-1893

Kondo H, Satomi M, Odera T (1954) Stemona alkaloids. XVI. Alkaloid from root of Stemona tuberosa. Ann Rept ITSUU Lab 5:99-102

Kongkiatpaiboon S, Schinnerl J, Felsinger S, Keeratinijakal V, Vajrodaya S, Gritsanapan W, Brecker L, Greger H (2011) Structural relationships of Stemona alkaloids: assessment of species-specific accumulation trends for exploiting their biological activities. J Nat Prod 74:1931-1938

Kongkiatpaiboon S, Mikulicic S, Keeratinijakal V, Greger H, Gritsanapan W (2013) HPLC simultaneous analysis for quality assessment of Stemona curtisii roots and determination of their insecticidal activities. Ind Crops Prod 43:648-653

Kostecki K, Engelmeier D, Pacher T, Hofer T, Vajrodaya S, Greger H (2004) Dihydrophenanthrenes and other 
antifungal stilbenoids from Stemona cf. pierrei. Phytochemistry 65(1):99-106

Koyama H, Oda K (1970) Crystal and molecular structure of stemonine hydrobromide hemihydrate. J Chem Soc B Phys Org. https://doi.org/10.1039/j29700001330

Lai DH, Yang ZD, Xue WW, Sheng J, Shi Y, Yao XJ (2013) Isolation, characterization and acetylcholinesterase inhibitory activity of alkaloids from roots of Stemona sessilifolia. Fitoterapia 89:257-264

Lee KY, Jeong EJ, Sung SH, Kim YC (2016) Stemona alkaloids isolated from Stemona tuberosa roots and their inhibitory activity on lipopolysaccharide-induced nitric oxide production. Rec Nat Prod 10:109-112

Leung PHH, Zhang L, Zuo Z, Lin G (2006) Intestinal absorption of Stemona alkaloids in a CaCo- 2 cell model. Planta Med 72:211-216

Li EX, Fu CX (2007) A new synonym of Stemona sessilifolia (Stemonaceae). Acta Phytotax Sin 45:399-402

Li SL, Jiang RW, Hon PM, Cheng L, Xu HX, Greger H, But PPH, Shaw PC (2007a) Quality evaluation of Radix Stemonae through simultaneous quantification of bioactive alkaloids by high-performance liquid chromatography coupled with diode array and evaporative light scattering detectors. Biomed Chromatogr 21:1088-1094

Li ZX, Sturm S, Stuppner H, Schraml E, Moser VA, Siegl V, Pfragner R (2007b) The dichloromethane fraction of Stemona tuberosa Lour inhibits tumor cell growth and induces apoptosis of human medullary thyroid carcinoma cells. Biol Targets Ther 1:455-463

Li YY, Wang YY, Taniguchi T, Kawakami T, Baba T, Ishibashi $\mathrm{H}$, Mukaida N (2010) Identification of stemonamide synthetic intermediates as a novel potent anticancer drug with an apoptosis inducing ability. Int J Cancer 127:474-484

Lim D, Lee E, Jeong E, Jang VP, Kim J (2015) Stemona tuberosa prevented inflammation by suppressing the recruitment and the activation of macrophages in vivo and in vitro. J Ethnopharmacol 160:41-51

Limtrakul P, Siwanon S, Yodkeeree S, Duangrat C (2007) Effect of Stemona curtisii root extract on P-glycoprotein and MRP-1 function in multidrug-resistant cancer cells. Phytomedicine 14:381-389

Lin WH, Fu HZ (1999) Three new alkaloids from the roots of Stemona tuberosa. J Chin Pharm Sci 8:1-7

Lin WH, Yin BP, Tang ZJ, Xu RS, Zhong QX (1990) The structure of parvistemonine. Acta Chim Sin 48:811-814

Lin WH, Xu RS, Zhong QX (1991a) Chemical studies on Stemona alkaloids I. Studies on new alkaloids of Stemona parviflora Wright C.H. Acta Chim Sin 49:927-931

Lin WH, Xu RS, Zhong QX (1991b) Chemical studies on Stemona alkaloids II. Studies on the minor alkaloids of Stemona parviflora Wright C. H. Acta Chim Sin 49:1034-1037

Lin WH, Ye Y, Xu RS (1991c) Studies on new alkaloids of Stemona mairei. Youji Huaxue 11:500-503

Lin WH, Ye Y, Xu RS (1991d) Studies on new alkaloids of Stemona mairei. Chin Chem Lett 2:369-370

Lin WH, Ye Y, Xu RS (1992) Chemical studies on new Stemona alkaloids, IV. Studies on new alkaloids from Stemona tuberosa. J Nat Prod 55:571-576
Lin WH, Cai MS, Ying BP, Feng R (1993a) Studies on the chemical constituents of Croomia japonica Miq. Acta Pharm Sin 28:202-206

Lin WH, Wang L, Qiao L, Cai MS (1993b) Two minor alkaloids from the roots of Stemona tuberosa L. Chin Chem Lett 4:1067-1070

Lin WH, Ma L, Cai MS, Barnes RA (1994) Two minor alkaloids from roots of Stemona tuberosa. Phytochemistry 36:1333-1335

Lin LG, Zhong QX, Cheng TY, Tang CP, Ke CQ, Lin G, Ye Y (2006) Stemoninines from the roots of Stemona tuberosa. J Nat Prod 69:1051-1054

Lin LG, Tang CP, Dien PH, Xu RS, Ye Y (2007a) Cochinchistemonine, a novel skeleton alkaloid from Stemona cochinchinensis. Tetrahedron Lett 48:1559-1561

Lin LG, Dien PH, Tang CP, Ke CQ, Yang XZ, Ye Y (2007b) Alkaloids from the roots of Stemona cochinchinensis. Helv Chim Acta 90:2167-2175

Lin LG, Li KM, Tang CP, Ke CQ, Rudd JA, Lin G, Ye Y (2008a) Antitussive stemoninine alkaloids from the roots of Stemona tuberosa. J Nat Prod 71:1107-1110

Lin LG, Leung HPH, Zhu JY, Tang CP, Ke CQ, Rudd JA, Lin G, Ye Y (2008b) Croomine- and tuberostemonine-type alkaloids from roots of Stemona tuberosa and their antitussive activity. Tetrahedron 64:10155-10161

Lin LG, Bao H, Wang A, Tang CP, Dien PH, Ye Y (2014) Two new $N$-oxide alkaloids from Stemona cochinchinensis. Molecules 19:20257-20265

Lind RJ, Greenhow DT, Blythe J, Goodchild J, Hirst E, Dunbar SJ, Earley FGP (2002) Cyanotropanes: novel chemistry interacting at the insect nicotinic acetylcholine receptor. The BCPC conference-pest \& diseases 2002. vol 1: 145-152. The British Crop Protection Council

Liu XY, Wang FP (2015) Recent advances in the synthesis of Stemona alkaloids. Nat Prod Commun 10:1093-1102

Manohar A (2013) In silico analysis of compounds from Stemona tuberosa as an inhibitor for $\mathrm{N} 1$ neuraminidase of H5N1 avian virus. Braz Arch Biol Technol 56:21-25

Mungkornasawakul P, Pyne SG, Jatisatienr A, Supyen D, Lie W, Ung AT, Skelton BW, White AH (2003) Stemocurtisine, the first pyrido[1,2,-a]azapine Stemona alkaloid. J Nat Prod 66:980-982

Mungkornasawakul P, Pyne SG, Jatisatienr A, Supyen D, Jatisatienr C, Lie W, Ung AT, Skelton BW, White AH (2004a) Phytochemical and larvicidal studies on Stemona curtisii: structure of a new pyrido[1,2-a]azepine Stemona alkaloid. J Nat Prod 67:675-677

Mungkornasawakul P, Pyne SG, Jatisatienr A, Lie W, Ung AT, Issakul K, Sawatwanich A, Supyen D, Jatisatienr C (2004b) Phytochemical studies on Stemona burkillii Prain: two new dihydrostemofoline alkaloids. J Nat Prod 67:1740-1743

Mungkornasawakul P, Chaiyong S, Sastraruji T, Jatisatienr A, Jatisatienr C, Pyne SG, Ung AT, Korth J, Lie W (2009) Alkaloids from the roots of Stemona aphylla. J Nat Prod 72:848-851

Mungkornasawakul P, Pyne SG, Willis AC, Jatisatienr A, Phuthsuk D, Lie W (2013) 6-Hydroxy-5,6-seco-stemocurtisine: a novel seco-stemocurtsine-type alkanoid. Phytochem Lett 6:602-605 
Noro T, Fukushima S, Ueno A, Miyase T, Iitaka Y, Saiki Y (1979) A new alkaloid, croomine, from Croomia heterosepala Okuyama. Chem Pharm Bull 27:1495-1497

Oginuma K, Horiuchi K, Fukuhara T (2001) Karyomorphology of two genera in Stemonaceae. Acta Phytotax Geobot 52:57-63

Pacher T, Seger C, Engelmeier D, Vajrodaya S, Hofer O, Greger H (2002) Antifungal stilbenoids from Stemona collinsae. J Nat Prod 65:820-827

Phuwapraisirisan P, Poapolathep A, Poapolathep S, Tip-Pyang S (2006) In vivo oxytoxin antagonistic effects of pyrrolizidine alkaloids from Stemona sp. and Asparagus racemosus. ACGC Chem Res Comm 20:17-19

Pilli RA, Rosso GB, de Oliveira MCF (2010) The chemistry of Stemona alkaloids: an update. Nat Prod Rep 27:1908-1937

Pudjiastuti P, Pyne SG, Sugiyanto Lie W (2012) Isolation of tuberospironine A, a novel croomine derivative from Stemona tuberosa. Phytochem Lett 5:358-360

Qian J, Zhan ZJ (2007) Novel alkaloids from Stemona sessilifolia. Helv Chim Acta 90:326-331

Ramli RA, Lie W, Pyne SG (2013) Alkaloids from the roots and leaves of Stichoneuron halabalensis and their acetylcholinesterase inhibitory activities. Nat Prod Commun 8:695-698

Ramli RA, Lie W, Pyne SG (2014) Alkaloids from the roots of Stichoneuron caudatum and their acetylcholinesterase inhibitory activities. J Nat Prod 77:894-901

Ramli RA, Pudjiastuti P, Tjahjandaric TS, Lie W, Rattanajak R, Kamchonwongapaisan S, Pyne SG (2015) Alkaloids from the roots of Stemona javanica (Kunth.) Engl. (Stemonaceae) and their anti-malarial, acetylcholinesterase inhibitory and cytotoxic activities. Phytochem Lett 11:157-162

Rinner B, Siegl V, Pürstner P, Efferth T, Brem B, Greger H, Pfragner R (2004) Activity of novel plant extracts against medullary thyroid carcinoma cells. Anticancer Res 24:495-500

Sakata K, Aoki K, Chang CF, Sakurai A, Tamura S, Murakoshi S (1978) Stemospironine, a new insecticidal alkaloid of Stemona japonica Miq. Isolation, structural determination and activity. Agric Biol Chem 42:457-463

Sakulpanich A, Attrapadung S, Gritsanapan W (2017) Insecticidal activity of Stemona collinsiae root extract against Parasarcophaga ruficornis (Diptera: Sarcophagidae). Acta Trop 173:62-68

Sastraruji T, Jatisatienr A, Pyne SG, Ung AT, Lie W, Williams MC (2005) Phytochemical studies on Stemona plants: isolation of stemofoline alkaloids. $\mathrm{J}$ Nat Prod 68:1763-1767

Sastraruji T, Jatisatienr A, Issakul K, Pyne SG, Ung AT, Lie W, Williams MC (2006) Phytochemical studies on Stemona plants: isolation of new tuberostemonine and stemofoline alkaloids. Nat Prod Commun 1:813-818

Sastraruji K, Pyne SG, Ung AT, Mungkornasawakul P, Lie W, Jatisatienr A (2009) Structural revision of stemoburkilline from an E-alkene to a Z-alkene. J Nat Prod 72:316-318

Sastraruji K, Sastraruji T, Pyne SG, Ung AT, Jatisatienr A, Lie W (2010) Semisynthesis and acetylcholinesterase inhibitory activity of stemofoline alkaloids and analogues. J Nat Prod 73:935-941
Sastraruji T, Chaiyong S, Jatisatienr A, Pyne SG, Ung AT, Lie W (2011) Phytochemical studies on Stemona aphylla: isolation of a new stemofoline alkaloid and six new stemofurans. J Nat Prod 74:60-64

Sastraruji K, Sastraruji T, Ung AT, Griffith R, Jatisatienr A, Pyne SG (2012) Synthesis of stemofoline analogues as acetylcholinesterase inhibitors. Tetrahedron 68:7103-7115

Schinnerl J, Kaltenegger E, Pacher T, Vajrodaya S, Hofer O, Greger H (2005) New pyrrolo[1,2-a]azepine type alkaloids from Stemona and Stichoneuron (Stemonaceae). Monatsh Chem 136:1671-1680

Schinnerl J, Brem B, But PPH, Vajrodaya S, Hofer O, Greger H (2007) Pyrrolo- and pyridoazepine alkaloids as chemical markers in Stemona species. Phytochemistry 68:1417-1427

Seger C, Mereiter K, Kaltenegger E, Pacher T, Greger H, Hofer O (2004) Two pyrrolo[1,2-a]azepine type alkaloids from Stemona collinsae Craib: structure elucidations, relationship to asparagamine A, and a new biogenetic concept of their formation. Chem Biodivers 1:265-279

Sekine T, Ikegami F, Fukasawa N, Kashiwagi Y, Aizawa T, Fujii Y, Ruangrungsi N, Murakoshi I (1995) Structure and relative stereochemistry of a new polycyclic alkaloid, asparagamine A, showing anti-oxytocin activity, isolated from Asparagus racemosus. J Chem Soc Perkin Trans I:391-393

Sun H, Dong W, Zhang A, Wang W, Wang X (2012) Ultraperformance liquid-chromatography with tandem mass spectrometry performing pharmacokinetic and biodistribution studies of croomine, neotuberostemonine and tuberostemonine alkaloids absorbed in the rat plasma after oral administration of Stemonae Radix. Fitoterapia 83:1699-1705

Takayama H, Ichikawa T, Kuwajima T, Kitajima M, Seki H, Aimi N, Nonato MG (2000) Structure characterization, biomimetic total synthesis, and optical purity of two new pyrrolidine alkaloids, pandamarilactonine- A and - $\mathrm{B}$, isolated from Pandanus amaryllifolius Roxb. J Am Chem Soc 122:8635-8639

Takayama H, Ichikawa T, Kitajima M, Aimi N, Lopez D, Nonato MG (2001) A new alkaloid, pandanamine; finding of an anticipated biogenetic intermediate in Pandanus amaryllifolius Roxb. Tetrahedron Lett 42:2995-2996

Tang CP, Chen T, Velten R, Jeschke P, Eppinghaus-Kintscher U, Geibel S, Ye Y (2008) Alkaloids from stems and leaves of Stemona japonica and their insecticidal activities. J Nat Prod 71:112-116

Tsai YC, Yu ML, El-Shazly M, Beerhues L, Cheng YB, Chen LC, Hwang TL, Chen HF, Chung YM, Hou MF, Wu YC, Chang FR (2015) Alkaloids from Pandanus amaryllifolius: isolation and their plausible biosynthetic formation. J Nat Prod 78:2346-2354

Umsumarng S, Pintha K, Pitchakarn P, Sastraruji K, Sastraruji T, Ung AT, Jatisatienr A, Pyne SG, Limtrakul P (2013) Inhibition of P-glycoprotein mediated multidrug resistance by stemofoline derivatives. Chem Pharm Bull 61:399-404

Umsumarng S, Pitchakarn P, Sastraruji K, Yodkeeree S, Ung AT, Pyne SG, Limtrakul P (2015) Reversal of human multi-drug resistance leukaemic cells by stemofoline derivatives via inhibition of P-glycoprotein function. Basic Clin Pharmacol Toxicol 116:390-397 
Umsumarng S, Pitchakarn P, Yodkeeree S, Punfa W, Mapoung S, Ramli RA, Pyne SG, Limtrakul P (2017) Modulation of P-glycoprotein by Stemona alkaloids in human multidrug resistance leukemic cells and structural relationships. Phytomedicine 34:182-190

Umsumarng S, Mapoung S, Yodkeeree S, Pyne SG, Limtrakul P (2018) A pharmacological strategy using stemofoline for more efficacious chemotherapeutic treatments against human multidrug resistant leukemic cells. Asian Pac J Cancer Prev 19:3533-3543

Wang FP, Chen QH (2014) Stemona alkaloids: biosynthesis, classification, and biogenetic relationships. Nat Prod Commun 9:1809-1822

Wang P, Liu AL, An Z, Li ZH, Du GH, Qin HL (2007a) Novel alkaloids from the roots of Stemona sessilifolia. Chem Biodivers 4:523-530

Wang P, Qin HL, Li ZH, Liu AL, Du GH (2007b) A new alkaloid from Stemona sessilifolia. Chin Chem Lett 18:152-154

Wang YZ, Tang CP, Dien PH, Ye Y (2007c) Alkaloids from the roots of Stemona saxorum. J Nat Prod 70:1356-1359

Wu YX, He HQ, Nie YJ, Ding YH, Sun L, Qian F (2018) Protostemonine effectively attenuates lipopolysaccharide-induced acute lung injury in mice. Acta Pharmacol Sin 39:85-96

Xiang J, Cheng S, Feng TL, Wu Y, Xie W, Zhang M, Xu XH, Zhang CF (2016) Neotuberostemonine attenuates bleomycin-induced pulmonary fibrosis by suppressing the recruitment and activation of macrophages. Internat Immunopharmacol 36:158-164

Xu RS, Lu YJ, Chu JH, Iwashita T, Naoki H, Naya Y, Nakanishi K (1982) Studies on some new Stemona alkaloids. A diagnostically useful 1H NMR line-broadening effect. Tetrahedron 38:2667-2670

Xu RS, Tang ZJ, Feng SC, Yang YP, Lin WH (1991) Studies on bioactive components from Chinese medicinal plants. Mem Inst Oswaldo Cruz, Rio de Janeiro 86(Suppl II):55-59

Xu YT, Hon PM, Jiang RW, Cheng L, Li SH, Chan YP, Xu HX, Shaw PC, But PPH (2006) Antitussive effects of Stemona tuberosa with different chemical profiles. J Ethnopharmacol 108:46-53

Xu YT, Shaw PC, Jiang RW, Hon PM, Chan YM, But PPH (2010) Antitussive and central respiratory depressant effects of Stemona tuberosa. J Ethnopharmacol 128:679-684
Yang XZ, Zhu JY, Tang CP, Ke CQ, Lin G, Cheng TY, Rudd JA, Ye Y (2009) Alkaloids from roots of Stemona sessilifolia and their antitussive activities. Planta Med 75:174-177

Ye Y, Velten RF (2003) Semi-syntheses of new stemofoline derivatives. Tetrahedron Lett 44:7171-7173

Ye Y, Xu RS (1992) Studies on new alkaloids of Stemona japonica. Chin Chem Lett 3:511-514

Ye Y, Qin GW, Xu RS (1994a) Alkaloids from Stemona tuberosa. Phytochemistry 37:1201-1203

Ye Y, Qin GW, Xu RS (1994b) Alkaloids from Stemona japonica. Phytochemistry 37:1205-1208

Ye Y, Qin GW, Xu RS (1994c) Alkaloids of Stemona japonica. J Nat Prod 57:665-669

Yi M, Xia X, Wu HY, Tian HY, Huang C, But PPH, Shaw PC, Jiang RW (2015) Structures and chemotaxonomic significance of Stemona alkaloids from Stemona japonica. Nat Prod Commun 10:2097-2099

Yue Y, Deng AJ, Xu DS, Qin HL (2013) Two new Stemona alkaloids from Stemona tuberosa Lour. J Asian Nat Prod Res 15:145-150

Yue Y, Deng AJ, Li ZH, Liu AL, Ma L, Zhang ZH, Wang XL, Du GH, Qin HL (2014) New Stemona alklaloids from the roots of Stemona tuberosa. Magn Reson Chem 52:719-728

Zhang RR, Tian HY, Wu Y, Sun XH, Zhang JL, Ma ZG, Jiang RW (2014) Isolation and chemotaxonomic significance of stenine- and stemoninine-type alkaloids from the roots of Stemona tuberosa. Chin Chem Lett 25:1252-1255

Zhong Y, Gao Y, Guo QP, Li WM (2010) Two new alkaloids from Stemona tuberosa. Helv Chim Acta 93:133-138

Zhou Y, Jiang RW, Hon PM, Xu YT, Chan YM, Chan TWD, Xu HX, Ding LS, But PPH, Shaw PC (2006) Analyses of Stemona alkaloids in Stemona tuberosa by liquid chromatography/tandem mass spectrometry. Rapid Commun Mass Spectrom 20:1030-1038

Zhou X, Leung PHH, Li N, Ye Y, Zhang L, Zuo Z, Lin G (2009) Oral absorption and antitussive activity of tuberostemonine alkaloids from the roots of Stemona tuberosa. Planta Med 75:575-580

Zou CY, Fu HZ, Lei HM, Li J, Lin WH (1999) New alkaloids from the roots of Stemona japonica Miq. J Chin Pharm Sci 8:185-189

Publisher's Note Springer Nature remains neutral with regard to jurisdictional claims in published maps and institutional affiliations. 